\title{
An Analytical Study of Impact of International Merger and Acquisitions on the Financial Performance for Higher Education Institution in the United States
}

http://doi.org/10.21272/fmir.4(4).5-30.2020

\section{Duane T. Frederick}

Researcher, Ed.D., MDIV., MA, USA

Karina Kasztelnik, ORCID: https://orcid.org/0000-0002-1090-3700

Professor of Accounting, Colorado State University-Global Campus, Aurora, CO, USA

\begin{abstract}
The paper summarizes the arguments and counterarguments within the scientific discussion on the issues such as higher education institutions, mergers and acquisitions, world class universities, integrated postsecondary educational data system in the United States. The main purpose of this scientific research study problem is the impact of international merger and acquisition on the financial performance for higher education institution in the United States. Synthesis of this topic has a significant impact on the financial well-being for all students and professors around the World. The methodology is the observation then synthesis all current and prior existing literature and facts available for the purpose of understanding the current financial situation for all higher education industry. The paper presents the results of a critical thinking analysis integrated postsecondary education data system. The U.S. Department of Education's National Center for Education Statistics for higher education institutions database system, called the Integrated Postsecondary Education Data System. This U.S. Government run database has collected annual higher education institutions level information since 1986 and by statute requires all Title IV higher education institutions to report in an accurate and timely manner to this database. This research contributed to the advancement of scientific knowledge in that it provided a research study on the interaction effects between time and merger status upon the performance metrics which generalize across regional, state, and national landscapes. Practical implications address how interested higher education institutions stakeholders can use this study to analyze the historical interaction effects between merger status and time on performance metrics which they wish to improve. The future implications discussion includes how this research study provided what researchers in the field have asked for and how this increased knowledge of merger and acquisitions longitudinal effects on performance metrics provides a framework for further study in this area.
\end{abstract}

Keywords: merger, acquisitions, higher education institutions, revenues

JEL Classification: H75, I21, I22, I23, F21, G34, G32, G38.

\section{(i)}

This work is licensed under a Creative Commons Attribution 4.0 International License

Cite as: Frederick, D. T., Kasztelnik, K. (2020). An Analytical Study of Impact of International Merger and Acquisitions on the Financial Performance for Higher Education Institution in the United States. Financial Markets, Institutions and Risks, 4(4), 5-30. http://doi.org/10.21272/fmir.4(4).5-30.2020.

(C) The Authors, 2020. This article is published with open access at Sumy State University.

\section{Introduction}

HEIs occupy an essential and meaningful role in the American and global cultural landscape. The historical mandates for HEIs remain as relevant today as they did in ancient Greece and $9^{\text {th }}$ century Morocco (Matthews, 2017). Many people value the cultural traditions, morals and societal values, and the skills and knowledge inculcated by post-secondary education. Because of this many Americans desire to see Western values inculcated and instilled in our young adults through HEI education (McIlroy, 2016). For these reasons, HEIs and the degrees they award have historically retained a favorable level of regard in the American consciousness (Wilson \& Ford, 2016). Because of this, Federal, State, and local governments have appropriated substantial financial resources to support public post-secondary HEIs and indirectly supported private HEIs through Title 
IV appropriations in the form of student financial aid. As a result, many of the finest and most prestigious HEIs and research laboratories in the world exist under the auspices of public HEIs.

\section{Review of the Literature}

The last few decades have seen a confluence of factors that served to precipitate the current crisis which HEIs seek to survive (Martin \& Samels, 2017). The literature indicates that the high regard for the HEI role in society has dimmed. For example, the State of Arizona has cut its public HEI appropriations by $54.9 \%$ from 20082018 and Louisiana has cut funding 38.3\% during the same time period (Mitchell, Leachman, \& Saenz, 2019). Over the last 25 years fiscal factors including: escalating costs in all areas, declining government appropriations and financial aid, growing government compliance costs, a shrinking pool of high school graduates, and shrinking persistence rates have caused a catastrophic economic disruption in the HEI sector (Martin \& Samels, 2017). The financial crisis of 2008 further exacerbated the fiscal pressure which undermined the ability of HEIs to maintain financial integrity (Moran, 2016). The financial meltdown of 2008 caused federal, state, and local governments to redirect and reduce appropriations for HEIs to other funding imperatives (Moran, 2016). Therefore, some HEI administrators believe that they have a greater imperative than ever before to initiate M\&A activity.

The literature predicts a massive change in the HEI landscape (Harden, 2013). Harden (2013) predicts that in the next fifty years about 2300 HEIs operating in the United States will cease operations. IPEDS reported 8,551 HEIs in its 2001 universe and had dropped to 6,857 HEIs in its 2018 universe. This means that in 17 years 1,694 HEIs have ceased to be represented in the IPEDS universe (U.S. Department of Education, 2018). The various causes for lack of inclusion in IPEDS include shrinkage due to M\&A activity, different reporting of HEI statistics within a larger HEI system (parent/child reporting), and HEI closures (Azziz et al., 2019; Jaquette \& Parra, 2014). If this trend continues thousands of professors will lose their jobs and the traditional residential college campus will become obsolete (Harden, 2013). The online education movement, global competition, and financial austerity measures has caused HEIs to review and revisit all aspects of HEI operations and has galvanized the move toward STEM programs (Azziz et al., 2017; Herbert \& Rothwell, 2015; Portnoi et al., 2014). Government leaders, HEI administrators, and many HEI stakeholders have prioritized achieving higher WCU ranking status because breaking into the top 500 HEIs in global rankings leads to increased revenues. Since WCU ranking organizations exhibit bias toward STEM programs and have become the arbiters of determining HEI quality on a global basis, liberal arts HEIs have experienced a disproportionate reduction in revenues. HEI presidents and board members believe that achieving an elevated status in the annual lists of WCU ranking organizations will aid in achieving regional, national, and global prestige and increased institutional viability (Azziz et al., 2017). Because of this HEI researchers interested in M\&A activities have requested more quantitative studies to examine the effects of M\&A activities on various performance metrics (Boling et al., 2017; Williams, 2017).

Higher education institutions (HEIs). Title IV HEIs serve as the unit of observation and occupy the focus of study in this dissertation. Considering state budget cuts and a perceived lack of support for HEI appropriations the study decided to review the question of HEI relevance for American society. Many governmental leaders say they support and value the public HEI sector but the actions of many lawmakers in recent budget decisions seem to refute their protestations of support (Mitchell et al., 2019). This begs the following question "Does American society still think that HEIs provide enough value to publicly support them?"

HEIs serve a greater public good than just educating students so that they can find greater remuneration in a skilled vocation. Historically, society valued education to produce well-rounded citizens who were capable of independent thought while inculcating the student with societal values (Pichugina \& Bezrogov, 2017; Siddiqi, 2018). Lately, another, more pragmatic, approach has exerted greater influence upon different HEIs and their programming, causing paradigm shifts in HEI core purposes and missions (Gaus, 2019). Due to the economic climate and the rise of WCU ranking organizations, STEM programs have become favored over classic liberal arts programs (Gaus, 2019). If the HEI's role has devolved to become nothing more that training more competent professionals to perform a certain function for greater remuneration, than the cost of the educational opportunity should be transferred to the graduate. However, if HEIs exist to produce citizens with certain core values that possess critical thinking skills which will benefit societal interests, then public investment seems warranted. Therefore, a review of HEIs and their role in various societies throughout history will contextualize 
the paradigmatic change from classic liberal arts to STEM programs and inform readers how these shifts have influenced American society in its valuation of the HEI sector.

The roots of Western education. The modern Western educational system has its roots in ancient Greece and Rome (Pichugina \& Bezrogov, 2017). One fundamental purpose of education for Greek society was the inculcation of Greek knowledge, culture, and traditions into each succeeding generation so that Greek values and progress would continue (Pichugina \& Bezrogov, 2017). The second purpose for education involved transforming students into scholars. This educational focus proposed to teach students how to think and reason with the hope that this education enabled students to become self-motivated life-long adherents of education (Pichugina \& Bezrogov, 2017). Finally, Greco-Roman education had a goal of educating students who had mastered principles rather than just knowing facts and skills. The ancient Greek teachers hoped that these graduates would have the ability to synthesize knowledge from various domains to solve problems and to think critically (Pichugina \& Bezrogov, 2017). For Greek culture, education served to develop individuals and to support society. Early American society imported these fundamental educational ideals from Europe which provided the foundational structures for the HEI educational system in the United States.

In other ancient societies, parents provided higher education through private tutors or through religious institutions (Courtenay, 1989). People of various faiths wanted their children to receive higher education for the preservation and advancement of knowledge, for critical thinking skills, and to inculcate cultural values and virtues into the student (Kenney, 2015; Pichugina \& Bezrogov, 2017; Siddiqi, 2018). Parents believed that education possessed tremendous benefits for their children and was necessary for their children to grow into their full potential (Pichugina \& Bezrogov, 2017).

The cathedral schools. In the $6^{\text {th }}$ Century, leaders in the Roman Catholic Church developed concerns regarding the paucity of theological thinking skills, reasoning ability, and virtue in their priests (Loka, 2017; Orme, 1981). Because of this, bishops began to educate priests in monasteries and cathedrals for the purposes of instilling sound doctrine, biblical knowledge, and priestly virtue (Loka, 2017; Orme, 1981). As the priests gathered, the formation of these groups turned the cathedrals into centers of academic learning which became known as cathedral schools, the precursor to the medieval European university (Molac, 2013). The curriculum taught to these priests included virtue, sound theology, and knowledge of the core tenants of the Christian faith, so that they could develop moral and theological convictions grounded in a reasoned faith (Courtenay, 1989).

Masjid Al-Qarawiyy University. The next major stage in the development of the HEI occurred in the $9^{\text {th }}$ century, when a Muslim woman named Fatima Al-Fihri built the Masjid Al-Qarawiyy University in Fez, Morocco (Siddiqi, 2018). Al-Fihri began Al-Qarawiyyin University to provide a place for the advanced teaching of tenants of the Islamic faith, develop cultural values and virtue in students, and preserve knowledge in the Muslim world. This mandate mirrored many of the foundational reasons for the rise of the Cathedral schools in Europe. Al-Qarawiyyin University has endured to become the oldest continuously operating university in the world and still trains students in the knowledge of Islam and the Quran, virtue, intellectual knowledge, and critical thinking skills (Siddiqi, 2018). It was also the first university known to confer formal degrees to graduates (Siddiqi, 2018). The university facilities and student housing originally resided and operated within the confines of the mosque and became a center of Islamic learning. Because many top Muslim intellectuals and philosophers of that time graduated from Al-Qarawiyyin University it became known as the premier educational institution in North Africa (Ahmed, 2016). Fatima Al-Fihri achieved enduring success in her goal of instilling academic and moral knowledge in the students of Al-Qarawiyyin University.

Medieval European universities. The next stage in the development of the HEI was the rise of the universities in Europe. Around 1100 AD the universities of Bologna, Paris, and Oxford were founded as centers of learning. The University of Bologna is one of the oldest continuously operating European medieval universities (Haskins, 1923). The University of Bologna established a multi-faceted University sometime before 1100 A.D. (Haskins, 1923). Though the university had a diversity of academic disciplines, it gained its reputation as the center for the study and rehabilitation of the Corpus Juris Civilis, which preserved the codified Roman law written by the Roman emperor Justinian (Haskins, 1923). The great medieval legal scholar Irnerius served as a resident professor at the University of Bologna and legitimized the professional study of law. This in turn served as an impetus for Bologna's reputation as a school of law (Haskins, 1923). The multifaceted nature of this university, along with its reputation as a center of legal thought, developed in its students and the Western world a respect for the rule of law (Haskins, 1923). Western society has reaped the benefits of that respect through peaceful transitions of power in government; a monetary system backed by faith in the government which helps build wealth; religious pluralism; and the recognition of fundamental rights for citizens which 
allow them to safely function in society (McIlroy, 2016). The underlying belief in the rule of law which forms the substratum of modern Western society, originated in ancient Rome and was revived in the West through the teachings of the University of Bologna in 1100.

The University of Paris emerged around 1150 AD from the cathedral school of Notre Dame (Sorbonne University, 2020). The university was composed of four colleges one of which was founded by Robert de Sorbon in 1253 (Sorbonne University, 2020). This college became known for its theological education and taught both Dante and Saint Thomas d' Aquinas, as well as a number of men who would become popes, scientists, and theologians like Abelard (Haskins, 1923). The University of Paris was highly reputed as a center for the humanities especially philosophy and theology and was the preeminent university of the time (Haskins, 1923). The University of Paris was so influential that it created the educational system most HEIs use today. This consisted of a curriculum of study for a certain period in a certain specific subject, tested by examination, and leading to a degree (Haskins, 1923). Many of the degrees themselves, like the bachelor, masters, and doctorates were established by the University of Paris (Haskins, 1923). Notable alumni of the University of Paris include Marie Curie, Pierre Curie, Thomas Becket, Vera Wang, Pope John XXI, Pope Honorius IV, Pope Innocent III, Edgar Degas, Francois Mitterrand, Desiderius Erasmus, and Boutros Boutros-Ghali. This list of University of Paris alumni provides tangible proof that developing students into thinking adults can enrich global society in science, philosophy, politics, medicine, fashion, theology, and leadership.

Researchers state that Oxford University holds the status as the oldest university in the English-speaking world (University of Oxford, 2018). Scholars do not know the exact founding date of Oxford University; however, professors gave instruction to students in 1096 and the HEI grew steadily until 1167 (University of Oxford, 2018). In 1167, Oxford University experienced rapid development after Henry II banned English students from attending the University of Paris (University of Oxford, 2018). The stated goal of Oxford University remains to inculcate education and experiences within students which enables them to develop and apply skills, values, and intellectual rigor to their future lives and vocations (University of Oxford, 2018). Alumni of Oxford University include J.R.R. Tolkein, Oscar Wilde, Stephen Hawking, David Cameron, Adam Smith, Tony Blair, T.S. Elliott, Walter Raleigh, Thomas Hobbes, Thomas More, C.S. Lewis, Bill Clinton, John Locke, Harper Lee, and Margaret Thatcher. These Oxford educated people have enriched the world through contributions in theology, literature, politics, art, science, and technology and reflects the heritage generated by societal investment in HEIs.

The beginnings of HEIs in America. Puritans who received their education at Oxford emigrated from England to the New World and established English speaking universities in the style of Oxford University (Hudson, 1939). In 1636, New England Puritans founded Harvard College, the first HEI in the American Colonies (Hudson, 1939). Many of these founding Puritans had graduated from Oxford and Cambridge and expressed concern about the problem of illiterate clergymen and congregations (Hudson, 1939). Colonial administrators and church leaders expressed concern that illiteracy led to a dearth of knowledge which prevented the uneducated populace from understanding the Holy Scriptures and the discourses of trained pastors (Hudson, 1939). Puritans believed that people who lacked understanding of sound biblical principles and virtue had greater vulnerability to violating moral imperatives thus proliferating sin in the surrounding culture. Beyond this concern the Puritans valued education because they believed education would raise the level of the colonial culture, produce graduates with independent minds, and encourage free inquiry (Potts, 1971). Therefore, these Puritans found it necessary, on behalf of the greater public good, to establish Harvard College for the training of men for the pastorate (Potts, 1971).

In the mid- $17^{\text {th }}$ Century the philosophical movement called the Enlightenment swept through Europe and caused a sea-change of philosophical and religious thought both in Europe and in the American colonies (Shaw, 2015). Shaw (2015) wrote that this movement elevated natural law and respect for human reason above that of religious authority and dogmatic theology. The Enlightenment emphasized the value of scientific inquiry above established unchallenged truths and the value of individual freedom above aristocratic authority and control. This influx of new ideas, brought to the colonies by enlightened immigrants, weakened the Puritan domination of religious and political thought.

The weakening of Puritan intellectual and religious hegemony allowed non-Puritans to establish the next wave of colonial HEIs. William III and Mary II chartered William and Mary College in 1693 and the Colony of Connecticut established Yale College in 1701 (Owens, 2011). William and Mary boast George Washington, Thomas Jefferson, John Tyler, and James Monroe as alumni and was the first law school in America (William 
and Mary, 2020). William and Mary alumni clearly had a profound impact in the formation of what would become the United States of America. Yale University Alumni include George H. W. Bush, George W. Bush, Meryl Streep, Eli Whitney, Paul Newman, John Kerry, William Jefferson Clinton, Hilary Clinton, Oliver Stone, Anderson Cooper, Sigourney Weaver, Jonathan Edwards, Dick Cheney, Vincent Price, Brett Kavanaugh, John C. Calhoun, Samuel Morse, Sonia Sotomayor, Nathan Hale, Cole Porter, and Gerald Ford (Browning, 2014). This list contains US presidents, a US Supreme Court justice, inventors, actors, composers, and theologians. This shows that the higher education output of Yale University has enriched US society.

In 1740, a Christian movement called the Great Awakening provided the impetus for the next wave of HEIs. This movement, led by George Whitfield and Jonathan Edwards, established pluralism as the sine qua non of the American religious and political landscape (O'Brien, 1986). Pluralism allowed the previously oppressed Christian separatists to establish centers of intellectual education that would challenge denominational educational hegemony (O’Brien, 1986). Harris (2013) stated that the competing denominational colleges like Princeton, Dartmouth, Brown, and Rutgers served the religious and political desires of their denominations.

Rationalism, tolerance, and a growing sectarian strength produced the next wave of colleges so that at the tail end of the $18^{\text {th }}$ century the College of New Jersey, King's College, College of Rhode Island, Queens College, and Dartmouth were established which provided the seeds of diversity that would address the educational needs of the new nation (Harris, 2013). The resulting freedom of religious self-determination and HEI government allowed Anglicans, Baptists, Dutch Reformed, and Presbyterians to establish these schools with their own religious distinctives (Harris, 2013).

The American Revolutionary War delayed the next wave of HEIs until after the resolution of the war, but the post-war years brought an acceleration of HEI charters. The victory of the colonies over the British and the constitutional mandates forbidding the establishment of state sponsored religion changed the focus from religious training toward a greater emphasis on secular learning and leadership (Harris, 2013). Americans wanted to excel in every area to show Europe that America had gained true independence from Europe, not just politically but economically, religiously, and educationally (Harris, 2013). By 1820 the number of colleges expanded from 25 HEIs at the dawn of the $19^{\text {th }}$ century to 52 and this growth continued to accelerate until there were 241 HEIs by the beginning of the Civil War (Harris, 2013).

Americans in the aftermath of the Revolutionary War expressed a renewed dedication to the American educational endeavor. They felt an educated populace provided leadership that served American interests and transmitted values that defended the new republic against tyranny and aggression which threatened liberty (Harris, 2013). Americans also believed that HEI education would raise the cultural level of society and that HEIs possessed a responsibility to train America's young people (Potts, 1971). Because of these perceptions, the HEI landscape in America experienced significant growth as HEIs sought to produce educated citizens in a new republic desiring to expand the American identity (Harris, 2013).

Land grant schools and the development of the modern HEI. The period after the Civil War saw the development of the American HEI into the form which American society now views as the standard American university (Harris, 2013). This type of university begins the post-secondary experience with general education for the freshman and sophomores and then follows up with specialized courses for the last two years (Harris, 2013). The standard American university concept changed the role of faculty and teaching from traditional recitation in classical education to lectures based on the faculty's expertise (Harris, 2013). Furthermore, the growth of specialized education caused HEIs to establish graduate programs which allowed students to further specialize in a profession.

The land grant schools expanded the specialization of HEI education to more pragmatic and utilitarian disciplines. The Morrill Act of 1862, signed by Abraham Lincoln, created the land-grant college movement which changed the educational landscape from solely educating the elites to educating the common person (Behle, 1996). This law granted US Federal land to the individual states for the purpose of establishing colleges which would teach practical arts such as agriculture, business, engineering, and marketing (Behle, 1996). These land-grant colleges were intended to provide a more utilitarian type of education to the industrial classes who were underserved by more traditional liberal arts HEIs (Behle, 1996). This forced universities as centers of specialized learning to expand libraries, training facilities, and research facilities to provide educational opportunities for these new branches of learning (Chen \& Schmidtke, 2017; Harris, 2013). Thus American HEIs experienced a shift away from just teaching classical, formalistic education toward a more pragmatic educational philosophy focused on applied sciences and occupational training programs (Behle, 1996). This 
shift toward specialized, utilitarian, training marked the advent of the large American research university which combined the offerings of practical degrees in applied sciences with classical degrees in liberal studies (Harris, 2013). The large research university fostered in early $20^{\text {th }}$ century America has now become the template for universities around the world and John Morrill's goal of achieving practical utilitarian education for the masses has expanded well beyond the land-grant system he proposed. Today this form of pragmatic education has evolved and spread to every corner of the world in the form of STEM HEIs. The land grant HEIs through their alumni have elevated US industrial and agricultural productivity and have fostered US economic expansion and prosperity.

The junior college. Further development of the utilitarian theme of education for the masses in the early years of the $20^{\text {th }}$ century saw a new kind of HEI established in the American post-secondary educational landscape (Harris, 2013). In 1901, Joliet Junior College became the first public junior college in America (Wilson \& Ford, 2016). The founders of this HEI stated that they desired to introduce college level courses to Chicago area high schools (Wilson \& Ford, 2016). Junior colleges, also known as community colleges, often serve as gateway HEIs to four-year colleges or universities. Deans of most junior colleges confer degrees at the subbaccalaureate level, including associate degrees and certificates for specific industry related courses of instruction (Crawford, 2014). Junior colleges typically cost substantially less than four-year colleges and universities and usually have agreements to allow transfer of graduates into four-year state schools which serves the democratic ideal of higher education accessible for all people. (Harris, 2013; Wilson \& Ford, 2016). In the modern era over 1,100 community colleges operate in the United States (Harris, 2013). Today, these junior colleges matriculate students eligible for Title IV federal financial aid and, like four-year HEIs, provide different educational paths for general education, liberal studies, applied sciences, and occupational training programs (Miller et al., 2016). Students who attend junior college with the intention of progressing to a fouryear HEI typically complete general education requirements at the more inexpensive tuition rate of the junior college.

Title IV HEIs. The U.S. Department of Education defines Title IV HEIs as post-secondary HEIs that the U.S. Department of Education has enabled to matriculate students eligible for Federal Financial Aid (U.S. Department of Education, 2018). This aid comes in the form of grants, student loans, and work study programs that allow students to finance their education (Rubin, 2011). The U.S. government uses Title IV financial contributions as an indirect means of funding HEIs (Rubin, 2011). Students spend this money on tuition, fees, room and board, and other tertiary costs related to attendance at an HEI (Rubin, 2011). Therefore, through the control of student funding, the U.S. government can also mandate certain core requisites that HEIs must possess to further the mission of the U.S. Department of Education in producing effective post-secondary educational outcomes.

IPEDS allows the sorting of HEIs into different categories depending on the focus of the study. One of the main ways which IPEDS sorts HEIs is by control of the institution. This category sorts the HEI into publicly administered HEIs, private non-profit HEIs, and private for-profit HEIs. IPEDS also sorts HEIs by size of the student population. This category sorts HEIs into 5 categories starting under 1,000 students; then 1,000-4,999; 5,000-9,999; 10,000-19,999; and 20,000 students and above. IPEDS also sorts HEIs by the type of degrees offered such as certificates, associates, bachelors, masters, and doctoral degrees. IPEDS sorts HEIs through Carnegie Classifications which relate to the programs offered by the HEI. This study utilized the IPEDS system and its ability to sort HEIs by category to identify the matching pair non-merging HEIs.

For over 1,200 years, people have depended on HEIs to provide opportunities through which students can develop qualities deemed important to their personal growth and the betterment of society. From ancient Greece to $9^{\text {th }}$ century Al-Qarawiyy University to the modern STEM research university, people have struggled to develop models of HEIs that will produce quality graduates. These qualities include: the ability to think, synthesize, and apply knowledge; to master principles that people will apply to solve societal issues; to respect the rule of law, and to inculcate in students a love for learning (McIlroy, 2016). Western society has historically tasked HEIs with the mandate to impart a sense of history and grounding in the resident culture so that the legacies and values of those cultures will be inculcated to the individual student (Doscher \& Landorf, 2018).

The advancement of technological prowess and to a lesser extent, inculcation of cultural values, has caused the United States federal government, other state and regional governmental entities, industry, and private individuals to spend billions of dollars every year to fund HEIs. In the United States, these financial outlays come in many forms including Title IV student financial aid, endowments, government appropriations, 
Financial Markets, Institutions and Risks, Volume 4, Issue 4, 2020 ISSN (online) - 2521-1242 ISSN (print) - 2521-1250

scholarships, research grants, patent licensing, and tuition. American society has historically valued educated and skilled people who can advance research and innovation within their disciplines for the betterment of society (Lavalle \& de Nicolas, 2017). For these reasons many Americans value and support the instrumental place HEIs occupy in achieving these objectives.

Mergers and acquisitions (M\&A). This study has chosen to focus on the interaction effects between time and HEI merger status upon performance metrics. This study selected merger status as the between subjects IV which requires a review of the components of merger status. The basic definition of an institutional merger refers to the melding of two or more institutions into one single organization controlled by a single governing body or individual (Harman, 2000). While this definition serves as the base definition of M\&A activity utilized in this study the literature has various labels for HEI unions (Azziz et al., 2019). Terms for HEI unions range from amalgamation, unification, federation, acquisition, takeover, consolidation, and merger all of which have different nuances (Azziz et al., 2019). For example, "consolidations" carry a connotation of a union of equals but the way a set of HEIs possess equivalence remains highly nuanced (Azziz et al., 2019). The literature speaks of equivalence in terms of student and faculty capitation, financial resources, branding, influence, political capital, name recognition, endowments, and many other metrics (Azziz et al., 2019). Each term used for a union of two or more HEIs possess a myriad of nuance that could confuse the usage of M\&A in the study. Therefore, this study uses and defines M\&A as a transaction in which two or more institutions combine all or some of their various component parts to operate as a single entity with a single governing body where at least one of the HEIs surrenders its independent identity (Azziz et al., 2019).

According to Pilcher (2017) mergers occur when two independent organizations decide that melding into one entity would prove beneficial to both organizations and so they combine to form a new merged organization. Each set of shareholders surrender their stock in the pre-merged entity and obtain new stock shares in new organization. Mergers possess characteristics of cooperation, deliberate planning, and desire from both sets of stakeholders in initiating and completing the transaction to meet external challenges and opportunities (Harman \& Harman, 2008; Pilcher, 2017).

The non-profit merger brings a variation to this because society owns non-profits and no individual human being owns a non-profit either individually or as a single body (McRay, 2019). The ownership of non-profit organizations are non-divisible and "ownership" rights cannot be transferred (McRay, 2019) In addition to this the government prohibits non-profit organization from behaving in a way which generates private inurement to individuals (Azziz et al., 2017; McRay, 2019). Finally, non-profit administrators retain accountability to state and federal authorities to ensure that any dissolution of the entity results in asset transfer only to another 501(c)(3) organization (McRay, 2019). Because of these distinctives, non-profit organizations add an additional layer of complexity to the merger process.

An acquisition occurs when one company purchases another company or entity. The acquiring organization possesses clear ownership of all aspects of the acquired entity which usually ceases its legal existence (Pilcher, 2017). The acquiring company's stock remains inviolate while the acquired company's identity and assets are subsumed into the acquiring company (Pilcher, 2017). Non-profit HEIs cannot acquire other non-profit organizations, however, a 501(c)(3) organization which ceases operations must transfer all assets, or proceeds from the sale of assets, to another non-profit organization, thereby providing de facto acquisition of the nonprofit HEI (McRay, 2019). Mergers and acquisitions (M\&A) signify the two major ways in which entities merge into one. While variations of these two types of merger exist, the basic consideration for this study's unit of observation remains the fact that two HEI entities became a single entity. Therefore, while this study recognizes that various types of M\&A initiatives exist, the form of M\&A activity does not significantly impact the study and therefore, the labels of mergers and acquisitions have been subsumed into the abbreviation M\&A.

Merger reasons. Organizations merge for a multiplicity of reasons. Some of these reasons include: empire building, solidifying strategic positions, managerial hubris, increasing market power, synergy gains, achieving economies of scale, acquiring physical plant and equipment assets, expanding the competitive scale of the organization, increasing bargaining power, diversification, expansion into international markets, survival, acquiring talent or patents, articulating new missions, and providing a justification for eliminating legacy systems and personnel (Azziz et al., 2017; Martin \& Samels, 2017; Pires \& Marcondes, 2017; Russell, 2017b).

Like for-profit organizations HEIs initiate M\&A activities for many of the same reasons. Sometimes HEIs merge with larger institutions to avoid closure due to insolvency issues (Bennett-Garraway, Langley, \& Chaffin, 2016; Martin \& Samels, 2017). Some HEIs merge with other HEIs for the purposes of long-term 
financial viability and strategic positioning (Bisoux, 2017). Still other HEIs desire to expand their international presence and find that a strategic merger becomes the most expedient way to expand globally (Tarba et al., 2017). Whatever the reason, a historical review of M\&A characteristics will inform the reader regarding the potential gains and inherent risks posed by initiating M\&A activities.

Merger types. Beyond the basic structure of M\&A previously described, mergers can be defined according to the relationships of the companies to be merged or acquired. The literature describes these relationships as horizontal, vertical, oligopolies, conglomerations, divestitures, and speculative mergers. The horizontal type of merger describes M\&A activity in which a company acquires a competitor, thereby causing market concentration (Hovenkamp \& Shapiro, 2018). Vertical mergers occur when a company buys its suppliers or downstream retailers to produce market power (Salop, 2018). Oligopolies exist as a type of quasi-merger and consist of a group of independent companies who collude to control an industry (Owen, 2006). Owen (2006) identifies conglomerations as another type of merger. He defines conglomeration as companies who diversify their business interests through M\&A activities in unrelated industries (Owen, 2006). Divestiture mergers occur when an organization acquires another organization and later divests itself of the entire acquired company or parts of the acquired company. In fact, the literature reports that acquiring companies divest themselves of $74 \%$ of unrelated acquisitions (Ma \& Wang, 2018). In the past divestiture mergers utilized hostile take overs and leveraged buyouts to acquire a conglomerate. Financiers then broke up the acquired conglomerate and sold parts of the conglomeration to other interested parties (Purina, 2017). Finally, speculative mergers form another type of merger. This type of merger occurs when a company acquires another company because the acquired company possesses a process, patent, or product which may turn into the next big idea (Purina, 2017). According to Purina (2017) all M\&A activities fall into these six categories of mergers.

History of $M \& A$ activities. Many people think of mergers and acquisitions as a relatively recent business innovation. In fact, history shows that many leaders have utilized M\&A activities as a tool to accomplish strategic objectives (Azziz et al., 2019). For example, during the years 550 to 538 BCE, King Cyrus of Persia used military force to merge the Medes and the Persians and then acquired Lydia and Babylon (Matthews, 2017). Two hundred years later, in 338 BCE, Philip of Macedon and his son Alexander conquered the armies of Athens and Thebes and coerced the remaining Greek city states to merge into a unified nation ruled by King Philip (Mouratidis, 1982). After the death of Philip, Alexander expanded Philip's M\&A policies and created one of the largest empires of the ancient world, stretching from the Adriatic Sea to Asia (Mouratidis, 1982). In the recent past, Vladimir Putin acquired Crimea through military force (Gedmin, 2014). Like Cyrus, Phillip, Alexander, and Putin, leaders throughout history have viewed mergers and acquisitions as expedient tools to achieve strategic objectives, although the means of implementing M\&A initiatives in the modern era has generally shifted from the use of military force towards more collaborative, financial, and legal vehicles.

Merger waves. M\&A activity in the industrial sectors emerged in the United States as a business phenomenon in late $19^{\text {th }}$ century and has increased in frequency since that time (Szücs, 2016). The phenomenon of M\&A activity often occurs in clusters over distinct periods of time, which the literature identifies as "merger waves" (Szücs, 2016). Researchers have traced merger waves to exogenous and endogenous shocks of specific industries resulting in the agglomeration of related industries (Andriuskevicius, 2017; Szücs, 2016). Due to agglomeration in an industry, business leaders take advantage of inefficiencies in their markets and utilize M\&A to acquire or merge assets to promote a more efficient alignment for their organization (Szücs, 2016). The mechanism of a merger wave starts with disruption in a business sector which provides business leaders with opportunities to inexpensively acquire strategic complementary assets and assimilate them, thereby increasing their company's strategic position. In turn, competing leaders see this type of strategic advantage by the competition as a threat and feel constrained to respond with M\&A activity of their own, thereby, propagating the merger wave (Warren, 2014).

Researchers have designated six major merger waves in the United States since the late $19^{\text {th }}$ century (Maksimovic, Phillips, \& Yang, 2013; Purina, 2017). The first major merger wave occurred during the late $19^{\text {th }}$ century and lasted until about 1905 (Owen, 2006). The second merger wave began about twenty years later because of a change in the regulatory framework governing interstate commerce in the United States and abruptly ended because of the exogenous shock of the Great Depression in 1929 (Owen, 2006). The next wave coincided with post WWII economic expansion and lasted until the early 1970s when the 1973 oil crisis curtailed expansion (Owen, 2006). The fourth merger wave began in 1980 and exceeded all previous merger waves in the number of transactions as well as the heightened fiscal expenditures for acquisitions (Owen, 
2006). Purina (2017) says that the fifth merger wave exceeded the fourth merger wave in both value and number of transactions. That wave began in the 1990s and peaked in the year 2000. The sixth merger wave began in the United States in 2003 and ended in 2007 (Purina, 2017). Some analysts speculate that a seventh mega-wave began in 2015 - 2016 caused by quantitative easing resulting in an estimated $\$ 4.7$ trillion in merger deals worldwide, but not enough data exists to confirm the analyst's speculations (Purina, 2017). In each distinctive merger wave, researchers discovered that each specific wave was characterized by a distinct type of merger initiated by leaders taking advantage of inequities in the marketplace and gaps in laws to achieve specific goals.

These merger waves represent periods of time in which agglomeration of various industrial sectors occurred due to disruptive exogenous and endogenous factors which made specific industry clusters vulnerable to M\&A activities. Researchers speculate that the first merger wave resulted from a combination of a rising and active Bull Market on Wall Street and the passage of the Sherman Anti-Trust Act of 1890 (Owen, 2006). Congress designed the Sherman Act to limit or prevent any agreements or contracts that limited interstate or international commerce (Owen, 2006). The unintended consequence of the Sherman Act caused companies to believe that this law restrained the US Government from acting to limit monopolies, which encouraged companies to consolidate and merge without concern for regulatory impediments (Owen, 2006).

The first merger wave. With regulatory compliance nullified and abundant capital, the first wave of M\&A activities occurred when business leaders decided to initiate horizontal mergers to create monopolies and eliminate their competition. Tin plate production in the United States combined under the American Tin Plate Company to capture $90 \%$ of tin plate production (Warren, 2014). The American Tin Plate Company accomplished this by combining multiple companies into one entity which controlled a total of 39 plants containing 279 mills (Warren, 2014). In June of 1899, the National Tube Company, which manufactured wrought-tube products, a type of steel pipe, combined 21 separate wrought-tube companies to become the leading national producer of wrought-tube, controlling $90 \%$ of the US wrought-tube market (Warren, 2014).

Andrew Carnegie merged multiple companies to create the Carnegie Steel Company, which became a major force in American raw steel production and instigated a rising trend of consolidation in the steel industry. In 1901, Carnegie sold his company to the United States Steel Corporation for $\$ 480$ million, culminating in the incorporation of the first company in history to have market capitalization of over \$1 billion (Warren, 2014). United States Steel came to dominate all aspects of steel production in the United States (Warren, 2014). The business climate which birthed the first wave produced intense competition in which weaker companies acquiesced to M\&A overtures by larger companies or became victims of the power of the monopoly (Owen, 2006).

John D. Rockefeller and the Standard Oil Company also rode the first merger wave to great success. Rockefeller established the Standard Oil Company of Ohio in 1870 by merging three separate refining partnerships (Moskowitz, 2018). From that point on, Rockefeller continued to buy competing refineries, discover new oil fields, and open retail service stations (Moskowitz, 2018). By 1880, researchers estimate that Rockefeller controlled at least $70 \%$ of petroleum production in the United States. To make matter worse for Standard Oil's competitors, Rockefeller used the market dominance of Standard Oil to force the railroads to provide discounted rates for the shipping of Standard Oil products (Moskowitz, 2018). In 1882, all Standard Oil companies consolidated into the Standard Oil Trust (Moskowitz, 2018). The consolidation of the oil industry did result in economies of scale, but in 1911 the Supreme Court of the United States (SCOTUS) found that the business of Standard Oil did substantially restrain the oil industry in the United States and ordered the breakup of Standard Oil into 34 separate companies (Moskowitz, 2018).

The first merger wave involved massive horizontal consolidations of approximately 70 industries including steel, oil, sugar, whisky, tobacco, and lead (Moskowitz, 2018; Owen, 2006). A bull market and the initial interpretation of the Sherman Antitrust Act limited government efforts to regulate monopolies. However, this changed when SCOTUS ruled that the Standard Oil Trust's business practices operated in such a way as to produce de facto restraint of trade and therefore became subject to government antitrust regulation under the Sherman Antitrust Act (Moskowitz, 2018).

The willingness of SCOTUS to break up the Standard Oil monopoly in 1911 put monopolistic trusts on notice that the US Government would no longer tolerate abuses of power, discriminatory practices, and excessive control of the markets (Owen, 2006). To that end, the United States Congress passed the Clayton Act in 1914 to remedy the weaknesses of the Sherman Antitrust Act and reduce the number of uncompetitive mergers 
(Owen, 2006). The Clayton Act prohibits mergers and uncompetitive business practices in a line of commerce or section of the country which might cause lower output and higher prices (Marinescu \& Hovenkamp, 2019).

Companies responded to the Clayton Act by forming oligopolies in which a small group of companies colluded to control a resource or commodity and have tremendous influence over one another in pricing and other market factors (Owen, 2006). At this point in history, multiple independent companies who controlled an industry seemed preferable to industries controlled by a single monolithic company, which allowed companies to collude with each other to skirt the provisions of the Sherman Antitrust Act and the Clayton Act. The unintended consequence of the Clayton Act provided the impetus for the second US merger wave.

The second merger wave. This wave began as a reaction to the passage of the Clayton Act and an active bull market (Owen, 2006). This wave focused on the food, paper, printing, and iron industries (Owen, 2006). The Clayton Act severely limited the merger and acquisition of horizontal companies. Therefore, to increase revenue the focus of companies shifted to controlling costs and improving efficiency through vertical mergers. This involved the purchase of companies that had previously sold or bought from the acquiring company (Salop, 2018). In theory, vertical mergers help to improve economies of scale and thereby provided a financial advantage and market power to the acquiring company (Salop, 2018). Vertical mergers provide the acquiring company with dedicated resources, reduced pricing, and coordination of production and supply (Salop, 2018). Furthermore, since raw materials, components, dedicated transportation, and dedicated retail outlets remain "in house", the company pays for these services at cost rather than negotiating and paying full market prices to independent companies (Salop, 2018). Finally, vertical mergers create situations in which competitors suffer a competitive disadvantage because of the lack of access to formerly available goods or services, also new entrants into that business sector face increased barriers to market entry (Salop, 2018). This type of merger saw numerous companies expand vertically rather than horizontally and characterized the second US merger wave which ended with the Great Depression of 1929.

The third merger wave. Companies of the third wave focused on corporate conglomeration, defined as companies diversifying their business interests through M\&A activities in unrelated industries (Owen, 2006). This wave began in the late 1950s and lasted until the oil crisis of 1973 (Owen, 2006). The focus on corporate conglomeration resulted from passage of the Celler - Kefauver Act, which further restricted horizontal corporate mergers (Owen, 2006). Companies circumvented the Clayton Act, which regulated horizontal mergers through the transfer of ownership in the acquired company, by avoiding acquisition of the target company. The Clayton Act does not limit the purchase of company assets and equipment. Therefore, to avoid regulatory interference, business leaders simply purchased ownership of a company's equipment and assets but did not purchase the company itself, thereby achieving a de facto horizontal merger without violating the Clayton Act (Audretsch, 1985). In response the US Congress passed the Celler - Kefauver Act which eliminated this form of horizontal merger and warned companies that the federal government would closely examine any intra-industry mergers (Audretsch, 1985). The threat of potential governmental scrutiny served to deter companies from intra-industry mergers and turned their merger strategy attention to unrelated industries. This precipitated the third merger wave and companies formed conglomerations through M\&A activities to invest excess corporate cash flows and provide a protective diversification hedge from exogenous shocks (Audretsch, 1985).

The fourth merger wave. This wave began in 1980 and surpassed all previous merger waves in the number of transactions and the acquisition cost of the companies (Owen, 2006). The circumstances triggering this wave resulted from the residual effects of the third wave (Owen, 2006). Conglomeration mergers turned industry focused horizontal companies into moribund behemoths which no longer specialized in a single industry (Purina, 2017). Because of this, managers skilled in managing one industry lacked the competence to direct acquired companies operating in completely different industrial sectors. The lack of industry expertise from the parent company became detrimental to the health of the acquired organizations and caused inefficiencies and reduced profits in those industries (Purina, 2017). Because of this, companies began divesting themselves of non-core operations, which actuated the fourth merger wave (Ma \& Wang, 2018; Owen, 2006).

Opportunistic financiers comprehended that the leaders of the conglomerates were lacking in knowledge of disparate industries and were also slow to respond to industry pressures. Therefore, these financiers acted to exploit the vulnerabilities of the conglomerates to generate profit. This gave rise to two major distinctives of the fourth merger wave: hostile takeovers and leveraged buyouts using high yield (junk) bonds (Owen, 2006). During that time, almost half of all major US companies found themselves the victims of unsolicited takeover 
bids (Owen, 2006). The people initiating the hostile M\&A activity would acquire conglomerates and then break up and sell the divested components to interested buyers (Purina, 2017). Financial innovations like junk bonds and leveraged buyouts gave these hostile corporate raiders the financial means to attempt hostile takeovers of many of the largest companies in the United States by borrowing money using the assets of the targeted business as collateral (Purina, 2017). The factors of financial innovation and hostile takeover opportunity created a $\$ 324$ billion wave, the largest up to that time in US business history. The fourth merger wave ended with the 1987 stock market crash and helped trigger the collapse of the junk bond market (Hurduzeu \& Popescu, 2015).

The fifth merger wave. Alan Greenspan (1996) characterized the fifth merger wave as one filled with "irrational exuberance" and believed that a collapsible financial bubble existed in the economy. The NASDAQ stock index composed mostly of technology stocks rose 1456\% from October of 1990 to March of 2000 (Purina, 2017). Unlike the previous waves, the fifth wave remained almost entirely non-hostile and the use of stock instead of debt as the primary medium of exchange increased to about $50 \%$ of M\&A transactions (Owen, 2006). Approximately $\$ 1.8$ trillion in M\&A transactions occurred during the 1990 s and resulted in significant value reduction of corporate stock values because of extensive overpayment, overvaluation, and the desire to do "mega-deals" (Purina, 2017). The high-tech industry epitomized these trends due to the difficulty in determining the future value of software or products (Purina, 2017). For example, when AOL financed the acquisition of Time Warner for $\$ 165$ billion in stock, the bid destroyed over $\$ 200$ billion of market value in the months following the announcement (Purina, 2017). Because of the amorphous nature of stock valuation on software and impacts on patents due to technological or medical advances, Greenspan (1996) stated that the "simple notion of price has turned decidedly ambiguous." This ambiguity caused by an incomplete understanding of the value of online marketing, market dominance of a computer operating system, and the value of an online social media program or search engine obfuscated the impact of these type of products on the present and future value of the producing companies. Thus, both parties in an M\&A transaction moved away from objective measures of value toward subjective measures of value (Purina, 2017). This merger wave ended with the dot.com crash (Purina, 2017).

The sixth merger wave. According to Purina (2017), the sixth merger wave started in the United States in 2003, began to subside in 2007 and ended with the 2008 financial market collapse. This merger wave produced about $\$ 1.53$ trillion in M\&A transactions. Many of the M\&A transactions used cash due to excess liquidity. The fifth wave's irrational exuberance transformed into rational exuberance as investors purchased companies using more discovery and concern over reasonable valuation (Purina, 2017). The 2008 financial crisis ended the sixth merger wave and demonstrated that irrational exuberance had shifted to the US housing market and the mortgage backed securities of the banking and mortgage securitization industries (Gilreath, 2018).

These merger waves resulted from numerous exogenous and endogenous forces that produced horizontal, oligopolies, vertical, conglomerate, divestiture, and speculative mergers in a multitude of business sectors. Though the nature of HEI non-profit organizations provided some insulation from the merger waves sweeping over other industrial sectors, the HEI sector does not possess immunity to M\&A mania. Some HEIs perform horizontal mergers to build up specific departments, to survive, or to acquire market power (Azziz et al., 2017; Kipchumba et al., 2016; Russell, 2017a). Other HEIs perform vertical mergers to obtain facilities and resources like labs, marketing departments, patents, and online educational departments (Bolbanabad et al., 2017). Many people in the United States and globally believe that for HEIs, "bigger is better" and actively pursue M\&A activities in ways reminiscent of the conglomeration activities of the third wave (Azziz et al., 2017). Like the fourth wave, some HEIs use M\&A activity to divest themselves of unwanted programs to concentrate talent and focus on a specific area of academic study (Bisoux, 2017; Docampo et al., 2015). Current pressures in the global financial markets have resulted in accelerated M\&A activity in the HEI sector to maintain international competitive parity (Pires \& Marcondes, 2017).

Merger outcomes. Researchers estimate that M\&A initiatives in all industrial sectors have, at least a $45 \%$ failure rate with some estimates ranging from $66 \%$ to as high as $75 \%$ (Ahammad et al., 2017; Boling et al., 2017; Smeets et al., 2016). Some researchers evaluate the success and failure of for-profit businesses based primarily on mean differences in conditions over time for financial measures (Cai \& Yang, 2015). Other researchers specify that the criteria for M\&A success or failure rests on the ability of the merger to create value in the post-merger organization (Ahammad et al., 2017; Boling et al., 2017). A third view defines failure or success of M\&A initiatives based on achieving expected efficiencies and economies of scale (Williams, 2017). Therefore, researchers define failures of for-profit M\&A initiatives based primarily on financial factors such 
as increased revenue, profit, capital, return on investment, and cost savings. Failing to meet stated financial objectives provides the basis for pronouncements of failure or success.

Much of the HEI M\&A literature has also judged M\&A initiatives for HEIs as successful based upon for-profit determinations of success. The weakness of this approach for the HEI sector involves the purposes behind the establishment of public HEIs and private HEI 501(c)(3) organizations. The purpose of a non-profit does not focus on wealth creation. Nor do individuals have the right to transfer assets from a non-profit for personal benefit. Therefore, the nature of 501(c)(3) non-profit organizations and their chartered purpose establishes an emphasis on non-fiscal goals which makes the assessment of M\&A success or failure more ambiguous than for-profit organizations. HEIs must possess financial viability to remain a functioning entity. However, HEIs have an added mandate to accomplish the mission which its founders established in the HEI charter. Therefore, HEI administrators must also balance fiscal concerns with the non-fiscal aspects of the organization (Azziz et al., 2019).

The financial crash of 2008 engendered a massive disruption in governmental financial support for HEIs (Jones, 2015). The reduced HEI appropriations threatened the solvency of many HEIs, especially smaller liberal arts HEIs (Moran, 2016). To counteract the effects of the economic downturn, HEI administrators adopted many different strategies such as redirecting administrative policy towards a neo-liberal outlook and developing online degree programs (Jones, 2015). The literature defines Neo-liberalism as the movement toward entrepreneurial freedom and free enterprise (Mahony \& Weiner, 2019). Thus, HEI administrators focused on Neo-liberal policies think of M\&A initiatives as possible strategies to improve organizational viability (Andreescu et al., 2015).

HEI leaders pursue M\&A initiatives to gain assets and resources that will provide the institution with licensing income, increased research revenue, increased tuition, and grant income. Unfortunately, many of these leaders initiate M\&A initiatives indiscriminately without the support of empirical data to inform their M\&A decision or provide them with objective benchmarks of M\&A success (Ahammad et al., 2017; Azziz et al., 2017; Risberg \& Meglio, 2012). M\&A initiatives which fail can place the viability of the HEI in jeopardy due to the high opportunity costs of M\&A initiatives. Empirical findings show $45 \%$ to $75 \%$ failure rates and despite this evidence the trend for HEI mergers continues to increase (Azziz, et al., 2017). Deschamps and Lee (2015) express concerns that the lack of objective, empirical research on the effects of M\&A activities on HEI DVs restricts the ability of HEI administration to effectively plan the future of their organizations. In any event, M\&A activities for HEIs will likely remain prevalent during the next few years and objectively quantifying M\&A activity results should provide value to HEI stakeholders (Martin \& Samels, 2017).

World class universities (WCUs). WCUs represent the epitome of high quality, successful HEIs (Kipchumba et al., 2016). Since HEI administrators initiate M\&A activity to improve the quality and success of their HEI a review of preeminent forms of successful HEIs seemed warranted. The literature defines a WCU as one of the top research universities identified by league rankings (Song, 2017). According to Kipchumba et al. (2016) WCUs comprise the preeminent form of HEIs and exhibit the following characteristics: a comprehensive offering of educational programs, superior outputs in research and teaching, innovation, facilities, world class faculty, and close ties with governments (both domestic and international), useful and efficient technology transfer to industry, and promotion of collaborative international research. Furthermore, WCUs attract faculty and students from around the world and maintain a reputation for producing educated and competent graduates and cutting-edge research (Kipchumba et al., 2016).

WCU ranking organizations. WCU ranking organizations have positioned themselves as arbiters of the relative success of HEIs which they rank on a national or global scale. Researchers have indicated that one of the issues in the field of M\&A for HEIs remains the lack of consensus regarding the selection of performance metrics as indicators for success (Boling et al., 2017; Pinhero et al., 2017). Current definitions of success for HEI M\&A initiatives depend on the frame of reference for the viewer. Some people define M\&A success in terms of enhancing the global prestige of the organization through advancement on WCU annual ranking reports (Azziz et al., 2017; Cantwell \& Taylor, 2013; Docampo et al., 2015; Shin, 2009). Other HEI administrators define success as the development of HEI research capacity (Altbach, 2004; Andreescu et al., 2015; Bolbanabad et al., 2017; Russell, 2017b). Many leaders consider M\&A activity successful if the HEI attains financial solvency and procures economies of scale (Moran, 2016; Pires \& Marcondes, 2017; Williams, 2017). Finally, for many academics, improving educational opportunities, developing innovation in research, partnering with industry, and enhancing research output signify M\&A success (Docampo et al., 2015; Olssen 
\& Peters, 2007; Smeets et al., 2016). Clearly, HEI stakeholders define M\&A success in different ways using different methods. This study assumes that administrators initiate M\&A activities to enhance their HEI's wellbeing. Therefore, an understanding of what constitutes a successful HEI will provide clarity for defining activities which strive to achieve HEI success. In the education arena a broad consensus by HEI administrators, faculty, governmental leaders, as well as students, parents, and the public currently exists on what defines a successful HEI.

College and university rankings have become one widely accepted measure of HEI success in the United States. Since 1983, US News and World Report (US News) has published an annual ranking of the top colleges and universities in the United States (Cantwell \& Taylor, 2013; Morse et al., 2017). Placing high in these rankings positively influences fall enrollment rates, nonresident alien rates, and revenues (Cantwell \& Taylor, 2013; Schuler, 2017). HEI leaders and stakeholders, government leaders, students and their parents, and leaders of industry often allocate financial resources to an HEI based on the annual ranking (Schuler, 2017). US News and its readers consider HEIs with the highest rankings as those that possess the highest quality and success among HEIs in the United States (Morse et al., 2017). Therefore, in the United States, the annual US News ranking report informs stakeholders about the relative success and quality of HEIs.

Like the US News annual ranking, WCU ranking organizations rank HEIs on a global level. Schools fortunate enough to achieve top 500 ranking placement on the various annual lists gain the imprimatur of a successful world class HEI (Docampo, 2012; Hazelkorn, 2017). The Times Higher Education's World University Rankings (TWUR), the QS World University Ranking (QS), and UMR have attained positions of prominence and regard as ranking agencies for establishing WCU status (Cantwell \& Taylor, 2013; Moed, 2016; Pietrucha, 2017). Cantwell and Taylor (2013) explain that these ranking systems award HEIs with global status and have stimulated global competition for top placement in these rankings. Hazelkorn (2017) believes that WCU rankings have shifted from simply influencing student choice to establishing geopolitical policy for HEIs. WCU rankings have grown in prominence and importance for HEI administrators, government policymakers, students and parents, as well as other stakeholders. Ranking reports help these people to make judgments regarding the comparative measure of HEI success (Docampo, 2012; Huang, 2015). The WCU ranking organizations judge HEIs in three main categories: teaching quality, research strength, and international outlook. To make their determinations, WCU ranking organizations utilize various performance metrics to judge each category. The criteria and performance metrics they use as indicators of quality for a successful HEI became the basis for the selection of performance metrics utilized in this study.

The Times Higher Education World University Ranking (TWUR). This WCU ranking organization places great weight on research output but also includes other metrics (Pietrucha, 2017). TWUR selected five overarching weighted ranking areas and 13 weighted performance metric categories within those areas to rank HEIs. According to Times Higher Education World University Rankings (2018) ranking areas and metric categories include: teaching (30\%), research $(30 \%)$, citations $(30 \%)$, international outlook $(7.5 \%)$ and industry income $(2.5 \%)$. TWUR utilizes five performance metrics when ranking an HEIs teaching environment. These metrics consist of a reputation survey $(15 \%)$, student/teacher ratio $(4.5 \%)$, doctorate to bachelor's degree ratio $(2.25 \%)$, doctorates awarded to academic staff ratio $(6 \%)$, and institutional income $(2.25 \%)$. For the research area TWUR utilizes the reputation survey (18\%), research income (8\%), and research productivity $(6 \%)$. The next area "Citations," equals the number of citations of faculty papers in scholarly work with no subcategories and weighs in at $(30 \%)$. TWUR judges international outlook through nonresident alien rates $(2.5 \%)$, international to domestic staff ratios $(2.5 \%)$, and international collaborations $(2.5 \%)$. The final area of TWUR rankings involves the area of industry income $(2.5 \%)$ which measures knowledge transfer (Times Higher Education World University Rankings, 2018). TWUR defines knowledge transfer as an HEIs ability to develop innovations, inventions, and help industry through consulting, which strengthens local and national industries and provides income to the HEI from those companies (Times Higher Education World University Rankings, 2018).

The QS World University Rankings (QS). This WCU ranking organization utilizes academic reputation $(40 \%)$, employer reputation $(10 \%)$, student/teacher ratio $(20 \%)$, citations per faculty $(20 \%)$, international faculty ratio (5\%), and international student ratio (5\%) to develop and publish rankings of the top 1000 schools in the world (The QS World University Rankings, 2019). These five metrics provide measures of three HEI institutional objectives: teaching, research, and international influence. To ascertain teaching quality the three metrics used by QS ranking organization focus on: academic reputation, employer reputation, and the student/teacher ratio (The QS World University Rankings, 2019). Citations per faculty indicate the research 
output of an HEI and international faculty ratios and international student ratios measure how the HEI performs in developing graduates with an international orientation (The QS World University Rankings, 2019).

The QS researchers utilized an academic survey in which over 80,000 respondents from the academy completed a survey about teaching and research quality at the world's universities (The QS World University Rankings, 2019). The QS World University Rankings (2019) conducts an additional survey to gather data to compile metrics for employer reputation. This survey remains the largest survey of its kind in the world and received over 40,000 responses from companies who were asked to identify which HEIs provide the most valuable new hires (The QS World University Rankings, 2019). QS researchers measure research output through dividing the total number of citations received by all papers over 5 years by the number of faculty members (The QS World University Rankings, 2019). QS researchers also study how HEIs prepare students to interact with a global economy. To that end, the QS rankings report on international faculty and international student ratios (The QS World University Rankings, 2019). The higher these metrics, the stronger the international reputation and brand, which tends to attract more international faculty and student talent (The QS World University Rankings, 2019). This in turn develops the ability of students to function in a multinational environment which employers perceive as valuable soft skill for potential hires (The QS World University Rankings, 2019).

$\boldsymbol{U}$-Multirank. This WCU ranking organization's researchers discount the validity of rankings which use a combined weighted score to place an HEI in a numbered league table (U-Multirank, 2018). They say that there exists no theoretical or empirical justification for this type of approach and appeal to studies that show these types of rankings can significantly change HEI positions on the table with a small alteration in weighting (UMultirank, 2018). Therefore, UMR concludes that this type of approach lacks the robustness necessary for consumers of HEI information to make informed decisions (U-Multirank, 2018).

UMR gathers data through voluntary HEI submissions covering over 120 data points which yield metrics providing data to determine rankings in teaching and learning, research, international orientation, regional engagement, and knowledge transfer (U-Multirank, 2018). HEIs report data via standardized questionnaires which UMR staff check for quality using automated and manual systems (U-Multirank, 2018). After the first phase of data collection, UMR asks for additional clarifications, questions and comments, and provides a second phase of data reporting that clarifies or corrects unclear or erroneous data. After this final submission of data, the researchers check the data once more and then calculate indicator scores (U-Multirank, 2018).

According to U-Multirank (2018), the 120 data points which HEIs submit for UMR rankings consist of questions like the other WCU ranking organizations. For example, UMR asks for revenues, fall enrollment rates, and nonresident alien rates (U-Multirank, 2018). UMR seems to provide the most comprehensive measures of performance metrics for HEIs. On the other hand, the basic components of what constitutes a successful school for UMR have distinct similarities to the other three ranking organizations. All the WCU ranking organizations view teaching quality, research output, and international orientation as important determinants for ranking the most successful HEIs in the world.

Creating WCUs. The idea of developing existing HEIs into WCU HEIs engenders considerable interest in the academic world. Each year these WCU rankings grow in influence as HEI leadership, national governments, and stakeholders strategize on moving up the rankings and prioritize creating WCUs as essential components of their national education agendas (Kipchumba et al., 2016; Zhao \& Qiao, 2017). HEIs that achieve a top 500 placement by WCU Ranking organizations in their annual lists can expect an increase in matriculation, revenues, international reputation, and many other tangible benefits (Cantwell \& Taylor, 2013).

In the United States, 20 million people apply to HEIs every year and many of these potential matriculants utilize rankings to identify HEIs to which they will submit applications (Schuler, 2017). HEIs with higher standings in the rankings capture a larger share of these 20 million matriculants because of the perception of quality that the comparative ranking bestows on the HEI (Cantwell \& Taylor, 2013). Rankings have grown to become one of greatest influences for HEI administrators in setting policy (Hazelkorn, 2017). Rankings have left the realm of simply enhancing student choice to setting benchmarks for WCUs and establishing geopolitical competitive positions for universities (Docampo et al., 2015; Hazelkorn, 2017). Cantwell and Taylor (2013) state that the presence of global rankings makes international competition and comparison of HEIs possible. Because of WCU rankings, HEI leaders, national policy makers, and other concerned stakeholders should account for the competitive global educational environment or risk falling into irrelevancy 
(Marginson \& van der Wende, 2007). The impacts of rankings on the global HEI environment has caused HEI leaders to become some of the biggest consumers of ranking information (Hazelkorn, 2017).

Governmental leaders, HEI administrators and stakeholders, parents of potential students, students, and the public have empowered WCU ranking organizations to provide definitive definitions of HEI success (Hazelkorn, 2017). Concurrently, the M\&A research community for HEIs has indicated the lack of definitive determinants and benchmark performance metrics defining M\&A success for HEIs (Boling et al., 2017). Researchers in the M\&A HEI field state that in higher education no clear metric has arisen that clearly defines the success or failure of a merger (Risberg \& Meglio, 2012). Therefore, most definitions of M\&A HEI success in the literature default to subjective, qualitative measures of success, and fiscal performance metric improvements which tend to exclude or underrepresent nonfinancial metrics (Gomes, Angwin, Weber, \& Tarba, 2013). Ultimately, this study assumes that HEI leadership initiates M\&A activities to move the HEI toward greater success. If WCU ranking organizations have become the arbiters of the comparative success of HEIs on a global level, then the factors which they use to make determinations of success could also serve as indicators of M\&A success for HEIs as well.

Both sets of inquiries share the same goal of identifying HEI success. HEI M\&A researchers experience a lack of consensus in defining one or more performance metrics for success because there is no "one" performance metric (Williams, 2017). Every HEI M\&A event and HEI possesses unique qualities and objectives relative to the M\&A initiative (Pires \& Marcondes, 2017). To make ranking determinations the WCU ranking organizations look at a plethora of metrics in the process of ranking HEIs. HEI administrators should determine which improvements in performance metrics will accomplish their vision of HEI success and see if M\&A activity has historically had the desired effect on that performance metric (Cantwell \& Taylor, 2013; Docampo et al., 2015; Hazelkorn, 2017; Kipchumba et al., 2016; Pietrucha, 2017; Risberg \& Meglio, 2012; Schuler, 2017). Therefore, since WCU ranking organizations utilize a plethora of performance metrics including revenue, fall enrollment rates, and nonresident alien rates to quantify teaching quality, research output, and international outlook, this study will adopt these three performance metrics as key indicators to determine the interaction effects between time and merger status upon these performance metrics (Pietrucha, 2017; Times Higher Education World University Rankings, 2018; U-Multirank, 2018).

Performance metrics. This study has selected the performance metrics of revenue, fall enrollment rates, and nonresident alien rates to serve as the DVs for examination. Therefore, a discussion of why these threeperformance metrics were selected will inform the reader of their contextual importance for WCU ranking organizations and for this study. The WCU ranking organizations examined in this study list teaching quality, research strength, and international outlook as components they use for ranking HEIs. The WCU ranking organizations employ the performance metrics of revenue, fall enrollment rates, and nonresident alien rates as determinants of HEI success in teaching quality (The QS World University Rankings, 2019; Times Higher Education World University Rankings, 2018; U-Multirank, 2018).

The ranking organizations determine research strength by using the following performance metrics: the number of citations generated by their faculty's writings, research revenue, faculty publishing rates, and awards granted to faculty (The QS World University Rankings, 2019; Times Higher Education World University Rankings, 2018; U-Multirank, 2018). Revenue in an indicator for many of these metrics and represents university research strength because financial wherewithal allows HEIs to build research laboratories, and to hire top research talent. This in turn promotes government and private industry investment and research contracts because they will spend their research dollars where they can obtain the greatest return on their investment resulting in increased revenues for the receiving HEI (OECD, 2017). This study views revenues as the total of all revenues and other additions which represent the sum of all revenues and other additions to net assets (U.S. Department of Education, 2018). Income accruing to an HEI includes but is not restricted to patent licensing, contractual agreements for research with public or private companies, governmental grants given for research, student tuition, fees, governmental appropriations, endowments, and alumni donations, as well as additional sources of income (Abdul-Alim, 2017; Hope, 2017; OECD, 2017).

Fall enrollment rates provide an indicator of teaching quality and teaching reputation. This DV also serves to indicate an increase in tuition revenue and HEI reputation. Fall enrollment rates include newly matriculating students as well as student persistence in pursuing their degree program.

When measuring international outlook and reputation, the ranking organizations employ international student ratios, international faculty ratios, and international collaborations to determine the rankings of HEIs in this 
area (The QS World University Rankings, 2019; Times Higher Education World University Rankings, 2018; U-Multirank, 2018). The WCU ranking organizations view international outlook as a vital component of producing well rounded, global citizens (Doscher, S., \& Landorf, H., 2018). International outlook Because the WCU ranking organizations use these performance metrics to evaluate the areas of teaching quality, research strength, and international outlook, this study will also use revenue, fall enrollment rates, and nonresident alien rates as performance metrics (DVs) for determining the effects of M\&A events on these HEI metrics.

Revenues. This study selected revenue as a dependent variable because this variable best represents the resources available to the HEI for development and improvement of facilities, equipment, staff, faculty, and research strength resulting in academic quality (Lavalle \& de Nicolas, 2017; Roberts, 2017). The performance metric of revenues strikes to the heart of contemporary society's beliefs concerning HEIs relevance. Since the advent of WCU ranking organizations, the criteria relating to the quality of an HEI has placed a heavy emphasis on HEI STEM research activities (Lavalle \& de Nicolas, 2017). Conducting and teaching research skills requires adequate research facilities and equipment to facilitate this type of training. Top quality research facilities and equipment represent a substantial outlay of capital. Therefore, revenues represent the ability of an HEI to provide these types of facilities. Societies trust HEIs to provide quality education with the goal of producing educated and functional professionals able to help meet industrial and societal needs (Lavalle \& de Nicolas, 2017). Therefore, those HEIs which governments and industry have entrusted with research contracts are assumed to have the facilities to do the research and develop students into competent employable professionals (Lavalle \& de Nicolas, 2017; Wichmann-Hansen \& Herrmann, 2017). An HEIs reputation for quality results in more tuition income, patent licensing income, research contract income, and governmental grants and subsidies (Cummings, 2014; Lavalle \& de Nicolas, 2017).

One of the assumptions of the Event Study approach includes an assumption that markets act efficient (McWilliams \& Siegel, 1997). Therefore, the Event Study theoretical framework postulates that governments and the private sector spend their research dollars where they believe they can receive the greatest value for their investment. HEIs that have demonstrated research competence through high-ranking WCU classification also display the HEI's relevance and position at the forefront of progress, research, and innovation and thus encourage outside investments (Lavalle \& de Nicolas, 2017).

From a practical standpoint, an HEI with a high WCU ranking generates more income in the form of research grants, contributions, donations, patent licensing, tuitions, and investment from the public and private sectors (Lavalle \& de Nicolas, 2017). HEIs that possess the most strength in these areas will generally receive the most funding from governments and industry and receive the most revenue from patent licensing and joint ventures with private industry (Cummings, 2014; Hope, 2017; Lavalle \& de Nicolas, 2017; OECD, 2017; Wichmann-Hansen \& Herrmann, 2017). Therefore, this study will utilize the performance metric revenues to represent the research strength of an HEI, its relevance to society, and the HEI's ability to provide a quality education that will produce qualified, competent, and educated professionals.

On the non-research side revenue also encompasses a revenue stream consisting of tuition, student fees, government subsidies, room and board income, and all other revenue that does not derive from the research activities of the HEI (Abdul-Alim, 2017; OECD, 2017). The WCU ranking organizations utilize revenue as a measure of the teaching quality of an HEI (Mukhopadhyay et al., 2018; Pietrucha, 2017). Revenues represent resources which the HEI can expend to improve teaching quality (Russell, 2017a). Revenue metrics serve as an indicator of teaching quality because of the ability of the HEI to purchase and upgrade equipment and facilities, to improve the quality of the educational experience, and the ability of HEIs to hire quality staff and faculty (OECD, 2017). Finally, revenues demonstrate the relative financial position of an HEI and its ability to remain viable (Tarba et al., 2017).

Fall enrollment rates. Fall enrollment rates, like revenues, indicate teaching quality. Parents choose to send their children s to HEIs so that they can obtain higher level employment after graduation (OECD, 2017; U.S. Department of Education, 2018). To that end, parents and students choose HEIs with a reputation for producing top quality, professionally competent graduates that companies desire to recruit after graduation (Lavalle \& de Nicolas, 2017). HEIs with increasing HEI reputation should experience increasing fall enrollment rates because of the perceived value of a degree from that HEI (OECD, 2017). Because of the perception that "good schools" lead to good jobs after graduation, WCU ranking organizations recognize that an HEI's reputation matters. Therefore, WCU ranking organizations choose to utilize matriculation rates as an indicator of a school's reputation, success, and teaching quality (Deschamps \& Lee, 2015; Hazelkorn, 2017; Moed, 2016). 
Nonresident alien rates. The nonresident alien rate performance metric reflects an HEI's outlook regarding globalization, the development of international trade and research, and the international exposure graduates possess to function in a global economy. This metric also measures the international reputation of an HEI for attracting and matriculating foreign students (Ahammad et al., 2017; Altbach, 2004; Portnoi et al., 2014). This study defines nonresident alien rates as the number of nonresident aliens who enroll in an HEI for credit during the official fall reporting date or October 15 (Delgado-Márquez et al., 2011; OECD, 2017; U.S. Department of Education, 2018). The attraction of international students to an HEI indicates its international reputation for teaching quality, particularly in STEM fields of study (Cantwell \& Taylor, 2013; Pietrucha, 2017; Schuler, 2017). IPEDS defines nonresident aliens as people who maintain their residence in the United States only on a temporary basis and who do not possess the right to reside in the United States indefinitely (U.S. Department of Education, 2018).

The nonresident alien rate performance metric also encapsulates the HEI's international reputation for cutting edge research, quality STEM education, the attraction of international talent including top students and proven international faculty, and the quality of international exposure to a global knowledge economy (Cantwell \& Taylor, 2013; Hazelkorn, 2017; Moed, 2016; OECD, 2017). For these reasons, international students choose to go to highly ranked schools based on WCU status derived from WCU ranking organization evaluations (OECD, 2017). On a practical note, international students generally pay non-resident tuition and fees which results in an increase of tuition revenue for the HEI (Palfreyman \& Tapper, 2016). As a result, nonresident alien rates have become a leading indicator of international performance and quality (OECD, 2017). The WCU world ranking organizations have recognized the importance of nonresident alien rates and incorporated nonresident alien rate performance metrics into their WCU rankings. This study will adopt nonresident alien rate as one of the study's DVs.

Integrated Postsecondary Educational Data System (IPEDS). IPEDS serves as the source of naturally occurring, historical data for this study. This review discusses IPEDS to inform the reader of the statistical strength and rigor that the NCES statisticians exercise in publication of the IPEDS annual statistics for the purpose of developing trust in the reliability and validity of the research data. HEI researchers have used this information to analyze many aspects of HEI operations and outcomes including an examination of market power effects of HEI M\&A initiatives, graduation rate analysis, and approaches which minority serving institutions take to carry out their missions (Boland, 2018; Ober et al., 2018; Russell, 2017a). IPEDS publishes statistical information on HEIs in IPEDS as public domain information, thereby fulfilling its mandate to collect and disburse HEI data for the betterment of the American educational system. IPEDS charges no fees nor does it place any restrictions regarding the usage of this database. IPEDS serves as the most extensive archival database for HEIs in the United States and because of this, the study will utilize IPEDS as its primary source of data for examination purposes.

The 1867 U.S. Department of Education Charter mandated the department to collect and make available to the public, educational data that shows the condition and progress of education in the United States for the betterment of the American educational system (Fuller, 2011). Since AY 1869/1870, the department has collected information regarding: enrollment, earned degrees conferred, and faculty data. During AYs 18701874, the U.S. Department of Education also began collecting library and financial data for HEIs (Fuller, 2011). In 1974, the Department of Education established the National Center for Education Statistics (NCES) and assigned to NCES the responsibility for collecting and disseminating education statistics in the United States (Fuller, 2011). To fulfill this mandate, NCES developed the precursor to IPEDS, the Higher Education General Information Survey (HEGIS) and implemented the data collection system in 1979 with the stated purpose of providing comprehensive institutional data on institutional characteristics, finances, enrollment data, conferral of degrees, faculty salaries, faculty, student charges, financial aid, migration, libraries, and physical facilities (Fuller, 2011).

In AY 1985/1986, NCES first began to phase in IPEDS as a replacement for HEGIS and achieved full operational status in AY 1988/1989 (Fuller, 2011). IPEDS expanded the scope of HEIs covered to include 12,052 institutions whose primary efforts provided postsecondary education programs to the public (Fuller, 2011). Since inception, IPEDS has added many other categories of data for collection including graduation rates, financial aid, and employees by assigned position categories. In 1992, IPEDS reporting for Title IV schools became mandatory and all HEIs in the United States who had enrolled students receiving federal financial aid became statutorily obligated to report data to IPEDS in a complete, timely, and accurate manner (Fuller, 2011). In the early $21^{\text {st }}$ century, IPEDS moved to a web-based reporting system for the purposes of 
reducing the reporting burden of HEIs and to increase the ease of access and utilization of data in the IPEDS database (Fuller, 2011).

IPEDS collects institution-level data from postsecondary institutions in the United States and defines postsecondary institutions as organizations open to the public which provide training beyond the high school level including two-year, four-year, graduate, doctoral, and vocational schools (Ginder, Kelly-Reid, \& Mann, 2017). The IPEDS survey collects data for twelve different components during three different seasonal reporting periods (Ginder et al., 2017). The fall data period collects data on institutional characteristics, completions, and twelve-month enrollments (Ginder et al., 2017). The winter data collection period assembles data for student financial aid, graduation rates, 200 percent graduation rates, admissions, and outcome measures (Ginder et al., 2017). The spring collection gathers data on fall enrollment, finance, human resources, and academic libraries (Ginder et al., 2017). Ginder et al. (2017) state that HEIs report this data to IPEDS via a web-based survey which automatically collates, totals, and averages data. IPEDS calculates percentages and gains using year before comparisons over the current year to detect abnormal data errors. The system also compares data with other related values as a quality control measure to ensure consistency of reporting. IPEDS releases preliminary data soon after the close of data collection; it releases provisional data approximately three months after IPEDS has fully reviewed, edited, and inputted the preliminary data. Final data for each component, including revisions, become available during the preliminary release of data during the next collection year (Ginder et al., 2017).

Ginder et al., (2017) report that IPEDS establishes its panel of reporting HEIs during the fall collection period. In AY 2016/2017, a total of 6,834 Title IV postsecondary institutions existed in the IPEDS universe. Of those, 218 HEIs that had participated in prior IPEDS data collection surveys did not report due to closure, merger, or discontinuation of postsecondary programs. An additional 445 postsecondary institutions surrendered reporting duties to parent institutions and IPEDS added 129 other HEIs to the IPEDS universe (Ginder et al., 2017).

The Institutional Characteristics portion of the IPEDS survey collects basic data on each institution. These characteristics include name, location, educational offerings, distance education, control or affiliation, admission requirements, fall enrollment, student services, student charges, and cost of attendance (Ginder et al., 2017). The Completions category or Graduation Rate collects data on degrees conferred during the July $1^{\text {st }}$ through June $30^{\text {th }}$ of the AY (Ginder et al., 2017). This includes degrees at the associates, bachelors, masters, and doctoral level as well as certificate completion programs (Ginder et al., 2017). This category also collects data on the number of degrees conferred by major, CIP code, degree level, race/ethnicity, and gender. The Graduation Rate component collects data on cohorts defined as full-time, first-time degree seeking students. This component also reports the number of students who completed their program within $150 \%$ of the normal time to completion. This category also collects data on the number of students who transferred to other institutions and the total number of students completing their programs on time (Ginder et al., 2017). Another component collects the same data for $200 \%$ graduation rates. The IPEDS data collection system generates summaries of these different categories for use by interested parties (Ginder et al., 2017).

The 12- month enrollment category collects data on unduplicated capitation enrollment and instructional activity data (Ginder et al., 2017). This portion of the survey also captures demographic data including race/ethnicity, and gender (Ginder et al., 2017). It also discovers the level of students in varying programs who enrolled during the reporting period and records the full-time or part-time status of students. The reporting of total graduate student full-time equivalency combines masters and doctoral student categories (Ginder et al., 2017).

Closely related to the 12-month enrollment category, the Admissions and Fall Enrollment categories collect data on admission requirements for first-time degree seeking potential matriculants. Data includes admissions test scores, secondary school records, number of applicants, number admitted, and the number enrolled (Ginder et al., 2017). The Fall Enrollment survey component consists of six separate parts: Part A collects data on the number, race, gender and enrollment status of students in the fall (Ginder et al., 2017). It also surveys the number of students enrolled exclusively in distance education courses (Ginder et al., 2017). The survey also asks for residence information and the number of students enrolled in the fall who had completed high school within the last twelve months (Ginder et al., 2017). Part E of the survey collects data on retention/persistence rates which track the percentage of returning students for their sophomore year (Ginder et al., 2017). 
Financial Markets, Institutions and Risks, Volume 4, Issue 4, 2020 ISSN (online) - 2521-1242 ISSN (print) - 2521-1250

The Finance component of the IPEDS survey collects summary data on the HEI financial status (Ginder et al., 2017). It includes revenues and expenses by source and type, changes in net assets, and scholarship expenditures (Ginder et al., 2017). HEIs also report endowment assets and income, and investment return (Ginder et al., 2017).

The IPEDS survey procedures utilize a web-based data collection system. Each HEI appoints a keyholder who can in turn appoint up to six more survey respondents. The keyholder shoulders the responsibility for HEI reporting, data integrity, and completeness (Ginder et al., 2017). In many institutions, keyholders can lock the data, which submits it to the IPEDS system. IPEDS sends keyholders notice in August of the academic year to register them and issue user ids and passwords in preparation for data collection (Ginder et al., 2017). IPEDS sends another email to alert keyholders of the opening of the data collection cycle. Online web-based survey instruments tailored for each HEI based on institutional characteristics includes preloaded data from the previous year for reference and comparison (Ginder et al., 2017). Once keyholders upload the data, they must correct all errors before the IPEDS system allows them to lock their data submission. If IPEDS staff detect any errors after the final review, they contact the HEI keyholder for further clarification (Ginder et al., 2017). After this process, the IPEDS data is downloaded to the IPEDS data center for provisional and final release (Ginder et al., 2017). The IPEDS system possesses automated data checking for all the categories in the survey using a year to year comparison for abnormal fluctuation in metrics (Ginder et al., 2017).

The IPEDS database creates the possibility of a unique view of interaction effects between non-profit M\&A HEIs and time upon DVs because of the mandatory nature of the IPEDS reporting mechanism. The IPEDS database system allows for a longitudinal study of DVs for 5 years subsequent to the merger of the Title IV HEIs and answers the need for data that sheds light on the many various aspects underpinning HEI public and private sector M\&A activities over time (Pinhero et al., 2017).

The following IPEDS studies from the literature served as examples to guide this study. Russell (2017a) utilized IPEDS in a study of the effects of M\&A activities on market power and student persistence. The research concluded that M\&A activities do generate market power for HEIs with an average increase in tuition and fee prices of 7\% (Russell, 2017a). The greatest price effects occurred for merged schools which offered degrees in the same areas of study and general geographic locations. Russell (2017a) showed that as local competition declined, the HEI raised prices due to its increased market power position. In that research, Russell (2017a) used IPEDS to study two DVs using an Event Study methodology to compare merger status and time for tuition and fee rates, and student persistence rates.

Ober et al. (2018) used IPEDS to perform a national longitudinal study of graduation rates from the years between 2000 and 2015 in the United States. This study distinguished between private and public universities, percentages of full-time and part-time enrollments, a variety of completion times such as $100 \%, 150 \%$, and $200 \%$ of completion times (Ober et al., 2018). The study found that a correlation did not exist between a state's two-year and four-year public institution graduation rates (Ober et al., 2018). The study by Ober et al. (2018) has characteristics like the proposed study in that it was a quantitative study which examined multiple HEI graduation rates.

A longitudinal qualitative study completed in 2017 measured the impact of M\&A activity on four groups of stakeholders. The study examined merger impacts on administrators, faculty, staff, and students using a survey designed specifically for each group of stakeholders. The survey asked 10 questions about how each of these groups of people perceived the impacts of the M\&A activity on them (Williams et al., 2017). Researchers developed surveys for each stakeholder group; therefore, instrumentation error may have affected the results of the survey. The findings of the administrator survey showed attitudes as the same or more positive in the post-merger period than the pre-merger period (Williams et al., 2017). For faculty the results showed attitudes as more negative post-merger (Williams et al., 2017). Staff responses to their survey seemed negative and generated the same response pre-merger to post-merger (Williams et al., 2017). The student survey results on attitude did not experience significant change and remained largely consistent pre-merger and post-merger (Williams et al., 2017). Though the two campuses merged all departments, the study only focused on the merging of the business departments (Williams et al., 2017). This qualitative longitudinal study did not generalize across a broad spectrum of HEIs across the United States (Tarba et al., 2017). A review of the M\&A HEI literature shows this type of study to be the predominant form of research in the M\&A HEI arena. While these types of studies have value, researchers also desire quantitative longitudinal studies to objectively identify the interaction effects between time and merger status upon specific DVs (Tarba et al., 2017; Williams, 2017). 
Methodology, instrumentation, and data sources. This study used a quantitative methodology and a causalcomparative (ex post facto) research design examining the interaction effects between time and merger status upon revenues, fall enrollment rates, and nonresident alien rates to provide quantifiable measures of M\&A initiative effects on those DVs for 80 Title IV HEIs located throughout the United States during the AYs 1988/1989 - 2013/2013 (McWilliams \& Siegel, 1997). The comparison population consisted of 80 matchingpair, non-merging Title IV HEIs located throughout the United States during the AYs 1988/1989 - 2013/2014 (McWilliams \& Siegel, 1997). The unit of analysis consists of Title IV HEIs located throughout the United States (Russell, 2017a). The study examined and performed a two-way mixed ANOVA analyses for each DV separately starting the year of the M\&A event and again 5 years subsequent to the merger to evaluate whether significant interaction effects occurred between time and merger status upon the separate DVs (McWilliams \& Siegel, 1997; Russell, 2017a; Vita \& Sacher, 2001). A five-year period was chosen by the study because obtaining accurate measurements requires the passage of three to 5 years subsequent to the M\&A event due to the disruption caused by the integration process (Bauer \& Matzler, 2014).

The U.S. Department of Education (2018) outlines the process for methodology, instrumentation, data sources and research materials in its annual methodology report. IPEDS establishes the annual IPEDS universe during the fall collection period. Each HEI appoints a keyholder which IPEDS recognizes as the responsible individual for submitting HEI data. For HEIs without an established keyholder NCES sends letters to the chief executive officers at those HEIs requesting that they designate a keyholder.

The web-based survey instruments contain many features designed to facilitate the quality and timeliness of the data. IPEDS tailors each online data entry form to each institution based on characteristics of institutional control, level of institution, types of awards offered, and calendar system. The online data entry forms also contained preloaded data from prior years for reference and comparison purposes. Upon completion of the data entry form the system required keyholders to run data entry checks to resolve any errors before they were able to submit the data. After submission, IPEDS automatically generates percentages and totals for each collection item and compares the current response to the data reported the preceding year. Responses outside the expected range were referred to IPEDS staff who conduct final reviews of the data and who contact the keyholder to resolve any discrepancies or problems. After IPEDS staff resolve any questions regarding the data they migrate the final data to the IPEDS Data Center. IPEDS collects self-reported data from HEIs in 12 separated categories during three seasonal reporting periods. The system also compares reported data with other reported values during the same year to check for consistency of reporting within each survey component and throughout the data collection program. HEI non-response to a survey component or missing data initiated a task for analysts to conduct imputations to provide a complete database. According to the U.S. Department of Education (2018) IPEDS applies a single imputation method for both HEI and item nonresponse. The Nearest Neighbor procedure identifies a responding HEI which possesses characteristics similar to the nonresponding HEI and utilizes that data as a substitute for the key statistics for each component (U.S. Department of Education, 2018).

Authors believe that the prior study (Delanoy, N \& Kasztelnik K) showed that the business open big data analytics can support innovative merger and acquisition process by using the novel technology.

\section{Summary}

The study used merger status as the between subjects IV for this study. Therefore, a review of various components and variations of M\&A activities and their effect on different industrial sectors seemed relevant. Though the M\&A activities in the HEI sector possess unique qualities the HEI non-profit sector shares many similarities to M\&A activities in the for-profit industrial sectors (Azziz et al., 2019). Therefore, the study undertook a literature review of M\&A to help define and contextualize M\&A for the reader. This section of the review provided a definition that this study implemented as its operating definition for M\&A. The review also discussed different nuances of M\&A initiatives by the categorical type of merger. This portion of the literature review provided the reader insight in understanding the categories involved in the history of M\&A activities in the United States. Following this, the review traced the history of M\&A activities in the United States beginning with the late $19^{\text {th }}$ century. The review discussed the interaction of M\&A waves, organizations, industrial sectors, and the US Federal Government.

Author Contributions: conceptualization, Duane T. Frederick and Karina Kasztelnik; methodology, Duane T. Frederick and Karina Kasztelnik; validation, Karina Kasztelnik; formal analysis, Duane T. Frederick and Karina 
Financial Markets, Institutions and Risks, Volume 4, Issue 4, 2020 ISSN (online) - 2521-1242 ISSN (print) - 2521-1250

Kasztelnik; investigation, Duane T. Frederick and Karina Kasztelnik; resources, Duane T. Frederick and Karina Kasztelnik; data curation, Duane T. Frederick and Karina Kasztelnik; writing - original draft preparation, Duane T. Frederick and Karina Kasztelnik; writing - review and editing, Karina Kasztelnik; visualization, Duane T. Frederick and Karina Kasztelnik; supervision, Karina Kasztelnik; project administration, Karina Kasztelnik.

\section{References}

1. Abdul-Alim, J. (2017). Report: Colleges' reliance on tuition revenue growing. Diverse Issues in Higher Education, 34(8), 7. Retrieved from http://go.galegroup.com/ps/retrieve.do?tabID=T002\& result ListType $=$ RESULT _LIST\&searchResultsType $=$ SingleTab\&searchType=AdvancedSearchForm\&currentPosi tion=1\&docId=GALE\%7CA493032719\&docType=Article\&sort=RELEVANCE\&contentSegment=\&prodI $\mathrm{d}=\mathrm{GPS} \&$ contentSet $=$ GALE\%7CA493032719\&searchId=R1\&userGroupName=nclivercc\&inPS=true

2. Ahammad, M. F., Tarba, S. Y., Glaister, K. W., Kwan, I. P. L., Sarala, R. M., \& Montanheiro, L. (2017). Motives for cross-border mergers and acquisitions: Perspective of UK firms. In S. Tarba, C. L. Cooper, R. M. Sarala, \& M. F. Ahammad (Eds.), Mergers and acquisitions in practice, 16-43. Routledge: New York. Retrieved from: https://business.leeds.ac.uk/publications/176/

3. Ahmed, S. (2016). Learned women: Three generations of female Islamic scholarship in Morocco. Journal of North African Studies, 21(3), 470-484. Retrieved from: https://doi.org/10.1080/13629387. 2016.1158110

4. Altbach, P. G. (2004). Globalisation and the university: Myths and realities in an unequal world, Tertiary Education \& Management, 10:1, 3-25. Retrieved from: https://www.tandfonline.com/doi/abs/10.1080/ 13583883.2004 .9967114

5. Andriuskevicius, K. (2017). M\&A performance and economic impact: Integration and critical assessment of methodological approach. Trends Economics and Management 29(2). 9-20. Retrieved from http://dx.doi.org/10.13164/trends.2017.29.9

6. Audretsch, D. B. (1985). The Celler Kefauver Act and the deterrent effect. Review of Industrial Organization, 2(4), 322-338. Retrieved from https://link.springer.com/article/10.1007/BF02418920

7. Azziz, R., Hentschke, G. C., Jacobs, B. C., Jacobs, L. A., \& Ladd, H. (2017). Mergers in higher education: A proactive strategy to a better future? New York, NY: TIAA Institute. Retrieved from: https://www.ey.com/Publication/vwLUAssets/ey-tiaa-institute-mergers-in-higher-education/\$File/ey-tiaainstitute-mergers-in-higher-education.pdf

8. Azziz, R., Hentschke, G. C., Jacobs, L. A., \& Jacobs, B. C. (2019). Strategic mergers in higher education. Baltimore: Johns Hopkins University Press. Retrieved from: https://jhupbooks.press.jhu.edu/title/ strategicmergers-higher-education

9. Bauer, F., \& Matzler, K. (2014). Antecedents of M\&A success: The role of strategic complementarity, cultural fit, and degree and speed of integration. Strategic Management Journal 35, 269-291. doi:10.1002/smj.2091. Retrieved from: https://onlinelibrary.wiley.com/doi/abs/10.1002/smj.2091

10. Behle, J. G. (1996). Scholars from the sod: The social origins and backgrounds of students at the University of Illinois, 1868-1894. (Doctoral dissertation) Retrieved from Proquest. (Order No. 9636695)

11. Bennett-Garraway, J. M., Langley, N. M., \& Chaffin, K. L. (2016). School closures and mergers: A business transaction impacting human capital. Practitioner Scholar: Journal of Counseling \& Professional Psychology, 5(1), 7-19. Retrieved from http://www.thepractitionerscholar.com/article/view/14353/10138

12. Bisoux, T. (2017). Achieving the effective on-campus merger. Bized, 16(4), 32-39. Retrieved from: https://bized.aacsb.edu/articles/2017/07/perfect-unions

13. Boland, W. C. (2018). The Higher Education Act and minority serving institutions: Towards a typology of Title III and V funded programs. Education Sciences, 8(33), 1-19. doi:10.3390/educsci8010033

14. Browning, L. (2014). The 22 most successful Yale alumni of all time. Business Insider. Retrieved from https:/www.businessinsider.com/most-notable-yale-alumni-2014-9

15. Cantwell, B., \& Taylor, B. (2013). Global status, intra-institutional stratification and organizational segmentation: A time-dynamic Tobit Analysis of ARWU position among U.S. universities. Minerva: A Review of Science, Learning \& Policy, 51(2), 195-223. doi:10.1007/s11024-013-9228-8

16. Cazan, S. A. (2017). Brexit implications over the England banking system - an Event Study approach. Journal of Public Administration, Finance \& Law, 11, 81-92. Retrieved from http://www.jopafl.com/uploads/issue11/Brexit_implications_over the England banking_system_an_Event Study approach.pdf

17. Chen, P., \& Schmidtke, C. (2017). Humanistic Elements in the Educational Practice at a United States SubBaccalaureate Technical College. International Journal for Research in Vocational Education and Training, 4(2), 117-145. doi: 10.13152/IJRVET.4.2.2 
18. Conner, B., \& Johnson, E. (2017). Descriptive statistics: Use these tools to analyze data vital to practiceimprovement projects. American Nurse Today, 12(11), 52-55. Retrieved from https://www.myamericannurse.com/wp-content/uploads/2017/11/ant11-Research-101-1017a.pdf

19. Courtenay, W. J. (1989). Inquiry and inquisition: academic freedom in medieval universities. Church History, 58(2), 168-181. Retrieved from: https://doi.org/10.2307/3168722

20. Crawford, W. (2014). Universities and four-year colleges in general. (2014). Library Technology Reports, 50(4), 26-36. Retrieved from https://journals.ala.org/index.php/ltr/article/view/4454/5188

21. Cummings, B. (2014). The changing landscape of intellectual property management as a revenue-generating asset for U.S. research universities. George Mason Law Review, 21(4), 1027-1047. Retrieved from http://www.georgemasonlawreview.org/wp-content/uploads/2014/06/Cummings-Website-Version .pdf

22. Das, S., Sen, P. K., \& Sengupta, S. (1998). Impact of strategic alliances on firm valuation. Academy of Management Journal, 41(1), 27-41. doi:10.2307/256895

23. Delgado-Márquez, B. L., Hurtado-Torres, N. E., \& Bondar, Y. (2011). Internationalization of higher education: Theoretical and empirical investigation of its influence on university institution rankings. RUSC: Revista De Universidad $Y$ Sociedad Del Conocimiento, 8(2), 265-284. Retrieved from https://doi.org/10.7238/rusc.v8i2.1069

24. Delanoy, N., Kasztelnik, K. (2020). Business Open Big Data Analytics to Support Innovative Leadership Decision in Canada. Business Ethics and Leadership, 4(2), 56-74. http://doi.org/10.21272/bel.4(1).56-74.2020.

25. Deschamps, E., \& Lee, J. (2015). Internationalization as mergers and acquisitions: Senior international officers' entrepreneurial strategies and activities in public universities. Journal of Studies in International Education 19(2). 122-139. doi:10.1177/1028315314538284

26. Docampo, D. (2012). Adjusted sum of institutional scores as an indicator of the presence of university systems in the ARWU ranking. Scientometrics, 90(2), 701-713. Retrieved from https://doi.org/10.1007/s11192-011$0490-\mathrm{y}$

27. Docampo, D., Egret, D., \& Cram, L. (2015). The effect of university mergers on the Shanghai ranking. Scientometrics, 104(1), 175-191. Retrieved from https://openresearchrepository.anu.edu.au/bitstream/1885/98756/6/01 Docampo The Effect of University 2015.pdf

28. Doscher, S., \& Landorf, H. (2018). Universal global learning, inclusive excellence, and higher education's greater purposes. Peer Review, 20(1), 4-8 Retrieved from https://www.aacu.org/peerreview/2018/Winter/FIU

29. Elbourn, E., Togher, L., Kenny, B., \& Power, E. (2017). Strengthening the quality of longitudinal research into cognitive-communication recovery after traumatic brain injury: A systematic review. International Journal of Speech-Language Pathology, 19(1), 1-16. doi:10.1080/17549507.2016.1193896

30. Field, A. (2013). Discovering statistics using IBM SPSS statistics, fifth edition. Thousand Oaks: Sage Publications Inc.

31. Fuller, C. (2011). The history and origins of survey items for the Integrated Postsecondary Education Data System, (NPEC 2012-833). U.S. Department of Education. Washington, DC: National Postsecondary Education Cooperative. Retrieved from https://nces.ed.gov/pubs2012/2012833.pdf

32. Gaus, N. (2019). Philosophy and politics in higher education: What are the roles of intellectual academics in Indonesian higher education?, Qualitative Research Journal, 19(3), 294-306. doi:10.1108/QRJ-12-2018-0008

33. Gedmin, J. (2014). Beyond Crimea: What Vladimir Putin really wants. World Affairs, 177(2), 8. Retrieved from http://www.jstor.org/stable/43556196

34. Gilreath, Z. S. (2018). The culprit of the Great Recession: A detailed explanation of mortgage-backed securities, their impact on the 2008 Financial Crisis, and the legal aftermath. Journal of Business \& Technology Law, 13(2), 319-336.

35. Ginder, S. A., Kelly-Reid, J. E., \& Mann, F. B. (2017). 2016-17 Integrated Postsecondary Education Data System (IPEDS) Methodology Report (NCES 2017-078). U.S. Department of Education. National Center for Education Statistics. Washington, DC. Retrieved from https://nces.ed.gov/pubs2017/2017078.pdf

36. Gomes, E., Angwin, D. N., Weber, Y., \& Tarba, S. Y. (2013). Critical success factors through the mergers and acquisitions process: Revealing pre- and post-M\&A connections for improved performance. Thunderbird International Business Review, 55(1), 13-35. doi:10.1002/tie.21521

37. Greenspan, A. (1996, December 5). Remarks by A. Greenspan [Transcription]. Annual Dinner and Francis Boyer Lecture of the American Enterprise Institute for Public Policy Research. Federal Reserve Archives, Washington, DC. Retrieved from https://www.federalreserve.gov/boarddocs/speeches/ 1996/1996120 5.htm

38. Harden, N. (2013). The end of the university as we know it. The American Interest (online). 
Financial Markets, Institutions and Risks, Volume 4, Issue 4, 2020 ISSN (online) - 2521-1242 ISSN (print) - 2521-1250

39. Harman, G. (2000). Institutional mergers in Australian higher education since 1960. Higher Education Quarterly, 54(4), 343. Retrieved from https://onlinelibrary.wiley.com/doi/abs/10.1111/1468-2273.00165

40. Harman, G., \& Harman, K. (2008). Strategic mergers of strong institutions to enhance competitive advantage. Higher Education Policy, 21(1), 99-121. https://doi.org/10.1057/palgrave.hep.8300172

41. Harris, M. (2013). Understanding institutional diversity in American higher education: Historical context of institutional diversity. ASHE Higher Education Report, 39(3), 17-35. doi:10.1002/aehe.20009

42. Haskins, C. H. (1923). The rise of universities. Ithaca: Cornell University Press.

43. Hazelkorn, E. (2017). Rankings and higher education: reframing relationships within and between states. Center for Global Higher Education working paper series, no. 19, Centre for Global Higher Educations, London. Retrieved from http://www.researchcghe.org/perch/resources/publications/wp19.pdf

44. Hope, J. (2017). Collaboration aims to boost startups based on university research. Dean and Provost, 18(10), 8. doi:10.1002/dap.30334

45. Hovenkamp, H., \& Shapiro, C. (2018). Horizontal mergers, market structure, and burdens of proof. Yale Law Journal, 127(7), 1996-2025. Retrieved from https://www.yalelawjournal.org/feature/horizontal-mergersmarket-structure-and-burdens-of-proof

46. Huang, F. (2015). Building the world-class research universities: a case study of China. Higher Education, 70(2), 203-215. doi:10.1007/s10734-015-9876-8

47. Hudson, W. S. (1939). The Morison Myth concerning the founding of Harvard College. Church History, 8(2), 148. doi:10.2307/3160652

48. Hurduzeu, G., \& Popescu, M. (2015). The history of junk bonds and leveraged buyouts. Procedia Economics and Finance 32(2015), 1268-1275. https://doi.org/10.1016/S2212-5671(15)01504-X

49. Jaquette, O., \& Parra, E. (2014). Using IPEDS for panel analyses: Core concepts, data challenges and empirical applications. In Paulsen, M. B. (Ed.), Higher education: handbook of theory and research. (pp. 467-533). https://doi.org/10.1007/978-94-017-8005-6 11

50. Jones, C. (2015). Openness, Technologies, Business Models and Austerity. Learning, Media and Technology, 40(3), 328-349. Retrieved from http://researchonline.limu.ac.uk/id/eprint/ 1763/1/Openness $\% 2 \mathrm{C} \% 20$ technologies\%2C\%20business\%20models\%20and\%20austerity-AOM.pdf

51. Kenney, G. C. (2015). Why religion matters and the purposes of higher education: a dialogue with Huston Smith. Zygon, 50(1), 227-244. Retrieved from https://doi.org/10.1111/zygo.12154

52. Kipchumba, S., Liu, Z., \& Liu, L. (2016). Paths for world-class universities in agricultural science. Higher Education, 71(1), 97-118. doi:10.1007/s10734-015-9891-9

53. Lavalle, C., \& de Nicolas, V. L. (2017). Peru and its new challenge in higher education: Towards a research university. Plos One, 12(8), 1-12. doi:10.1371/journal.pone0182631

54. Loka, N. (2017). The development of education in medieval Albania. European Journal of Economics, Law, and Social Sciences, 1(1), 93-105. Retrieved from http://iipccl.org/wp-content/uploads/2017/01/93-105.pdf

55. Ma, Q., \& Wang, S. (2018). A unified theory of forward- and backward-looking M\&As and divestitures. European Financial Management, 24(3), 418-450. doi:10.1111/eufm.12131

56. Mahony, P., \& Weiner, G. (2019). Neo-Liberalism and the State of Higher Education in the UK. Journal of Further and Higher Education, 43(4), 560-572. Retrieved from https://doi.org/10.1080/0309877X.2017.1378314

57. Maksimovic, V., Phillips, G., \& Yang, L. (2013). Private and public merger waves. The Journal of Finance, 68: 2177-2217. doi:10.1111/jofi.12058

58. Martin, J., \& Samels, J. (2017). Consolidating colleges and merging universities: New strategies for higher education leaders. Baltimore: The Johns Hopkins University Press.

59. Matthews, D. (2017). Moses as a royal figure in the Pentateuch with the edict of Cyrus as a test case. Restoration Quarterly, 59(2), 65-78. Retrieved from https://www.ixtheo.de/Record/491088884

60. McIlroy, D. (2016). How is the rule of law a limit on power? Studies in Christian Ethics, 29(1), 34-50. https://doi.org/10.1177/0953946815611112

61. McRay, G. (2019, May 10). Who really owns a nonprofit? [Web log post] Retrieved from https://www.501c3.org/who-really-owns-a-nonprofit/

62. McWilliams, A., \& Siegel, D. (1997). Event studies in management research: Theoretical and empirical issues. The Academy of Management Journal, 40(3), 626-657. doi:10.2307/257056

63. Miller, M. T., Grover, K. S., Deggs, D. M., D’Amico, M., Katsinas, S. G., \& Adair, L. (2016). Adult education in community colleges: New challenges to old problems. MPAEA Journal of Adult Education, 45(2), 17-23. Retrieved from https://search.proquest.com/openview/0b436f02a 4fea98eb5ae6e0b594c 3b33/1?pqorigsite $=$ gscholar $\& \mathrm{cbl}=28962$ 
64. Mitchell, M., Leachman, M., \& Saenz, M. (2019). State higher education funding cuts have pushed costs to students, worsened inequality (Center on Budget and Policy Priorities, October 24, 2019). Retrieved from Center on Budget and Policy Priorities website: https://www.cbpp.org/research/state-budget-and-tax/statehigher-education-funding-cuts-have-pushed-costs-to-students

65. Moed, H. F. (2016). A critical comparative analysis of five world university rankings. Scientometrics 15, 1-24. Retrieved from https://arxiv.org/ftp/arxiv/papers/1611/1611.06547.pdf

66. Molac, P. (2013). Historical overview of the evolution of the formation of candidates to the priesthood. Seminary Journal, 19(3), 9-17. Retrieved from https://login.lopes.idm.oclc.org/login?qurl=https:/ leds.a.ebscohost.com $\% 2$ feds $\% 2$ fpdfviewer $\% 2$ fpdfviewer $\% 3$ fvid $\% 2520 \% 3 \mathrm{~d} 1 \% 26 \mathrm{sid} \% 3 \mathrm{~d} 1 \mathrm{da} 5 \% 2520 \mathrm{~d} 5 \mathrm{~b} 2$ $\% 25206 \mathrm{abe}-\% 25204 \mathrm{acb}-8 \mathrm{fb} 2-0 \mathrm{eb} 3 \mathrm{fedd} 09 \mathrm{~d} 6 \% 2540$ sessionmgr4007

67. Moran, K. A. (2016). Organizational resilience: Sustained institutional effectiveness among smaller, private, non-profit US higher education institutions experiencing organizational decline. Work, 54(2), 267-281. doi:10.3233/WOR-162299

68. Morse, R., Brooks, E., \& Mason, M. (2017). How U.S. News calculated the 2018 best college rankings. Retrieved from https://www.usnews.com/education/best-colleges/articles/how-us-news-calculated-therankings

69. Moskowitz, D. B. (2018). Busting trusts: Standard Oil Company of New Jersey V. the United States, 1911221 U.S.1 Restraint of Trade. American History, 53(1), 24-25. Retrieved from https://www.library.caltech.edu/eds/detail?db=edsggo\&an=edsgcl.523767524\&isbn=edsggo

70. Mouratidis, J. (1982). Alexander the Great and his promotion of Greek games in the East. Canadian Journal of History of Sport, 13(1), 61-73. Retrieved from www.jstor.org/stable/43609383

71. Mukhopadhyay, P., Tapaswi, M. P., Sudarsan, P. K., \& Sudarsan, K. (2018). Assessing the quality of higher education institutions in India: An alternative framework. Current Science, 114(6), 1167-1173. doi:10.18520/cs/v114/i06/1167-1173

72. Ober, D. R., Beekman, J. A., \& Pierce, R. L. (2018). Analyzing four-year public university and two-year college graduation rates. Journal of Education and Training Studies, 6(4), 221-247. doi:10.11114/jets.v6i4.3129

73. O'Brien, S. (1986). A transatlantic community of saints: The Great Awakening and the first Evangelical network, The American Historical Review, 91(4), 811-832. doi:10.2307/1873323

74. Olssen, M., \& Peters, M. A. (2007). Neoliberalism, higher education and the knowledge economy: From the free market to knowledge capitalism. Journal of Education Policy 20(3), 313-345. Retrieved from https://doi.org/10.1080/02680930500108718

75. Orme, N. (1981). Education and learning at a medieval English cathedral: Exeter 1380-1548. The Journal of Ecclesiastical History, 32(3), 265-283. https://doi.org/10.1017/S0022046900031419

76. Osborne, J., \& Waters, E. (2002). Four assumptions of multiple regression that researchers should always test. Practical assessment, research \& evaluation, 8(2), 1-9. Retrieved from https://www.researchgate. net/profile/Jason_Osborne2/publication/234616195_Four_Assumptions_of_Multiple_Regression_That_Rese archers_Should_Always_Test/links/59302555aca272fc55e144da/Four-Assumptions-of-Multiple-RegressionThat-Researchers-Should-Always-Test.pdf

77. Owen, S. (2006). The history and mystery of merger waves: A UK and US perspective (Working paper 200602). Sydney: School of Banking and Finance, University of New South Wales. Retrieved from http://scholar.googleusercontent.com/scholar?q=cache:Ch1AEr0xsfsJ:scholar.google.com/\&hl=en\&assdt=0,4 $\underline{4}$

78. Owens, J. (2011). Enlightenment and education in eighteenth century America: A platform for further study in higher education and the colonial shift, Educational Studies, 47(6), 527-544. doi: $10.1080 / 00131946.2011 .621073$

79. Pietrucha, J. (2017). Country-specific determinants of world university rankings. Scientometrics 114(3), 11291139. Retrieved from https://doi.org/10.1007/s11192-017-2634-1

80. Pilcher, G. G. (2017). Mergers and acquisitions: A primer for those who implement M\&A decisions but do not make them. Coatingstech, 14(3), 44-53. Retrieved from https://www.paint.org/article/mergers-acquisitionsprimer-implement-ma-decisions-not-make/

81. Pinhero, R., Aarrevaara, T., Berg, L. N., Geschwind, L., \& Torjesen, D. O. (2017). Strategic mergers in the public sector: comparing universities and hospitals. In S.Y. Tarba, C. L. Cooper, R. M. Sarala, \& M. F. Ahammad (Eds.), Mergers and Acquisitions in Practice (pp. 44-68). New York: Routledge. 
Financial Markets, Institutions and Risks, Volume 4, Issue 4, 2020 ISSN (online) - 2521-1242 ISSN (print) - 2521-1250

82. Pires, M. G., \& Marcondes, R. C. (2017). Relevant factors in the post-merger systems integration and information technology in Brazilian banks. Brazilian Business Review,14(2), 160-181. doi:10.15728/bbr.2017.14.2.2

83. Potts, D. B. (1971). American colleges in the Nineteenth century: From localism to denominationalism. History of Education Quarterly, 11(4), 363-380. doi:10.2307/367036

84. Purina, N. (2017). Overvaluation theory and the wave effect in the 1990s US merger wave. Journal of Business Management, 2017(14), 27-43.

85. QS World University Rankings. (2019). Methodology [Website] Retrieved from https://www.topuniversities.com/qs-world-university-rankings/methodology

86. Rao, S. V. D. N., \& Sreejith, U. (2014). Event Study methodology: A critical review. The Macrotheme Review 3(1), 40-53. Retrieved from http://macrotheme.com/yahoo site admin/assets/docs/3MR31ASr.1334942.pdf

87. Risberg, A., \& Meglio, O. (2012). Merger and acquisition outcomes - is it meaningful to talk about high failure rates? In Y. Weber (Ed.). Handbook of research on mergers and acquisitions (pp. 147-167). Northamption: Edward Elgar Publishing, Inc.

88. Roberts, J. (2017). In times of geopolitical and economic instability how can innovative technologies drive new revenue opportunities for institutions and research funding in the UK? Insights, 30(2), 17-22. http://doi.org/10.1629/uksg.361

89. Rubin, R. (2011). The Pell and the poor: A regression-discontinuity analysis of on-time college enrollment. Research in Higher Education, 52(7), 675-692. doi:10.1007/s11162-011-9215-6

90. Russell, L. (2017a). Market power effects of college and university mergers (Job market paper). Cambridge: Department of Economics, Massachusetts Institute of Technology. Retrieved from https://pdfs.semanticscholar.org/6ee1/97b79bf25f895a24c7a954bfc0678f9a60db.pdf

91. Russell, L. (2017b). Short-term impacts of college consolidations: Evidence from the University System of Georgia. Unpublished manuscript, Nelson A. Rockefeller Center for Public Policy and the Social Sciences, Darmouth College, Hanover, NH. Retrieved from https://cpb-us-e1.wpmucdn.com/sites.dartmouth.edu /dist/3/ 1325/files/2017/08/Russell USGConsolidations 2017.pdf

92. Russell, L. (2018). Online data appendix; Market power effects of college mergers. Unpublished manuscript, Nelson A. Rockefeller Center for Public Policy and the Social Sciences, Darmouth College, Hanover, NH. Retrieved from https://cpb-us-e1.wpmucdn.com/sites.dartmouth.edu/dist/3/1325/ files/2018/02/Online DataAppendix PriceEffects.pdf

93. Salop, S. C. (2018). Invigorating vertical merger enforcement. Yale Law Journal, 127(7), 1962-1994. Retrieved from http://dx.doi.org/10.2139/ssrn.3052332

94. Schuler, D. (2017). What do we rank when we rank colleges? Who determines how and who benefits? Student empowerment and the development of alternative college rankings. Radical Teacher, 108, 36-41. doi:10.5195/rt.2017.359

95. Shan, G., Bernick, C., \& Banks, S. (2018). Sample size determination for a matched-pairs study with incomplete data using exact approach. British Journal of Mathematical \& Statistical Psychology, 71(1), 60-74. doi:10.1111/bmsp.12107

96. Shaw, E. (2015). Educational lessons from the past: marketing textbooks during the age of enlightenment (16th to 18th centuries). Journal of Historical Research in Marketing, 7(3), 389-406. Retrieved from http://dx.doi.org/10.1108/JHRM-05-2015-0014

97. Shin, J. C. (2009). Building world-class research university: The brain Korea 21 project. Higher Education, 58(5), 669-688. Retrieved from https://doi.org/10.1007/s10734-009-9219-8

98. Shin, J. C., Lee, S. J., \& Kim, Y. (2013). Research collaboration across higher education systems: maturity, language use, and regional differences. Studies in Higher Education 38(3), 425 - 440. Retrieved from https://doi.org/10.1080/03075079.2013.774585

99. Siddiqi, R. (2018). Oldest library of University of Al-Qarawiyyin in Fez, Morocco. Pakistan Library \& Information Science Journal 49(3), 69-73. Retrieved from https://web.b.ebscohost.com/abstract?direct $=$ true\&profile $=$ ehost\&scope $=$ site\&authtype $=$ crawler\&jrnl $=00309956 \& \mathrm{AN}=130449659 \& \mathrm{~h}=\mathrm{GNwU} 3 \mathrm{kFvsrGr}$ OLFTYfCh2t5AWWdB7ftuVEqWEK0wym6IPWWitBxd\%2f5\%2bHJNVB9ndC\%2bdW7u\%2fr9TA1uw7 IxN3wqrA\%3d\%3d\&crl=c\&resultNs=AdminWebAuth\&resultLocal=ErrCrlNotAuth\&crlhashurl=login.aspx \%3fdirect $\% 3$ dtrue $\% 26$ profile $\% 3$ dehost $\% 26$ scope $\% 3$ dsite $\% 26$ authtype $\% 3$ dcrawler $\% 26 j$ jrnl $\% 3$ d00309956\%2 6AN\%3d130449659

100. Skodvin, O. J. (2014, August). Merger as an instrument to achieve quality in higher education - rhetoric or reality? Paper in track 1 presented at the meeting of EAIR 36th Annual Forum, Essen, Germany. Retrieved 
from https://www.nokut.no/contentassets/5c0dd71da3cf49da98e9675673cceda1/skodvin_ole-jacob_merger as an instrument to achieve quality in higher education rhetoric or reality 082014.pdf

101. Smeets, V., Ierulli, K., \& Gibbs, M. (2016). An empirical analysis of post-merger organizational integration. Scandinavian Journal of Economics, 118(3), 463-493. doi:10.1111/sjoe.12161.

102. Song, J. (2017). Creating world-class universities in China: strategies and impacts at a renowned research university. Higher Education, 75(4), 729-742. doi:10.1007/s10734-017-0167-4

103. Sorbonne University. (2020). [Website] Retrieved from https://www.sorbonne-universite.fr/

104. Sorescu, A., Warren, N. L., \& Ertekin, L. (2017). Event Study methodology in the marketing literature: An overview. Journal of the Academy of Marketing Science, 45(2), 186-207. doi:10.1007/s11747-017-0516-y

105. Szücs, F. (2016). The triggers and clustering properties of merger waves. Applied Economics, 48(56), 54855496. doi:10.1080/00036846.2016.1178849

106. Tarba, S. Y., Cooper, C. L., Sarala, R. M., \& Ahammad, M. F. (2017). Mergers and acquisitions in practice: A state-of-art and future directions. In S.Y. Tarma, C. L. Coopert, R. M. Sarala, \& M. F. Ahammad (Eds.), Mergers and Acquisitions in Practice, 1-4. New York: Routledge.

107. Times Higher Education World University Rankings. (2018). World University Rankings 2018 methodology [Website]. Retrieved from https://www.timeshighereducation.com/world-universityrankings/methodology-world-university-rankings-2018

108. U-Multirank. (2018). Consortium of the Centre for Higher Education, Centre for Higher Education Policy Studies, Centre for Science and Technology Studies. U-Multirank: About-data sources and verification. [Website]. Retrieved from https://www.umultirank.org/about/methodology/our-approach/

109. University of Oxford. (2018). [website]. Retrieved from https://www.ox.ac.uk/

110. U.S. Department of Education. (2018). Institute of Education Sciences, National Center for Education Statistics, Integrated Postsecondary Education Data System. Retrieved from [website] https://nces.ed.gov/ipeds/

111. Vita, M. G., \& Sacher, S. (2001). The competitive effects of not-for-profit hospital mergers: A case study. The Journal of Industrial Economics 49(1). 63-84. Retrieved from https://pdfs.semanticscholar.org/c724/699207dd9c976a314f6 8f9ef6ff2b 0fb9193.pdf

112. Warren, K. (2014). Big steel: the first century of the United States Steel Corporation 1901-2001. Pittsburg: University of Pittsburg Press.

113. Wichmann-Hansen, G. G., \& Herrmann, K. (2017). Does external funding push doctoral supervisors to be more directive? A large-scale Danish study. Higher Education, 74(2), 357-376. doi:10.1007/s10734-016-00526

114. William and Mary. (2020). [Website] . Retrieved from https://www.wm.edu/about/history/index.php

115. Williams, H., Feldman, L., \& Conners, S. (2017). Impact of an instructional merger on four internal stakeholder groups of a college of business. Journal of Academic Administration in Higher Education, 13(2). 21-30. Retrieved from https://files.eric.ed.gov/fulltext/EJ1155848.pdf

116. Williams, J. (2017). Collaboration, alliance, and merger among higher education institutions. OECD Education Working Papers, No. 160, Paris: OECD Publishing. Retrieved from http://dx.doi.org/10.1787/cf14d4b5-en

117. Wilson, K. B., \& Ford, C. D. (2016). Moberly Junior College, the four-year junior college. History of Education, 45(6), 739-757. Retrieved from https://doi.org/10.1080/0046760X.2016.1181795

118. Zhang, J., Mohammad, F. A., Shlomo, T., Cooper, C. L., Glaister, K. W., \& Wang, J. (2015). The effect of leadership style on talent retention during merger and acquisition integration: Evidence from China. The International Journal of Human Resource Management 26(7), 1021-1050. Retrieved from https://doi.org/10.1080/09585192.2014.908316

119. Zhao, S. X., \& Qiao, L. (2017). Subject ranking of universities. Current Science, 113(7), 1214-1215. Retrieved from https://www.currentscience.ac.in/Volumes/113/07/1214.pdf 